\title{
Regenerating the Historic Urban Landscape through Circular Bottom-Up Actions: The Urban Seeding Process in Rijeka
}

\author{
Marco Acri *, Saša Dobričić and Maja Debevec
}

Citation: Acri, M.; Dobričić, S.; Debevec, M. Regenerating the Historic Urban Landscape through Circular Bottom-Up Actions: The Urban Seeding Process in Rijeka. Sustainability 2021, 13, 4497. https:// doi.org/10.3390/su13084497

Academic Editor: Luigi Fusco Girard and Christian Ost

Received: 9 February 2021

Accepted: 14 April 2021

Published: 17 April 2021

Publisher's Note: MDPI stays neutral with regard to jurisdictional claims in published maps and institutional affiliations.

Copyright: (c) 2021 by the authors. Licensee MDPI, Basel, Switzerland. This article is an open access article distributed under the terms and conditions of the Creative Commons Attribution (CC BY) license (https:/ / creativecommons.org/licenses/by/ $4.0 /)$.
University of Nova Gorica, Graduate School, Cultural Heritage Studies; Glavni trg 8, SI-5271 Vipava, Slovenia; sasa.dobricic@ung.si (S.D.); maja.debevec@ung.si (M.D.)

* Correspondence: marco.acri@ung.si;

Abstract: The increasing pressure on urban resilience and the parallel interest in the preservation of the Historic Urban Landscape (HUL) have opened new frontiers of research that find, in the principles of the circular economy, good responses. Cities need to remake themselves from pure consumption to more resilient and circular centers, finding inspiration in their cultural and natural heritage and the history that generated it. The City of Rijeka, Croatia, one of the partners in the CLIC project (an EU-funded Horizon 2020 research project entitled "Circular models Leveraging Investments in Cultural heritage adaptive reuse"), represents an exceptional example of how to manage the change from an industrial port city to a more sustainable and citizen-oriented living space, looking at the potentials of the cultural and historical layers as opportunities for the population. The City of Rijeka, aware of such potentials, applied successfully as a European Capital of Culture 2020 (ECoC 2020), while unlikely facing the negative impacts of the COVID-19 pandemic. In Rijeka, thanks to the CLIC Heritage Innovative Partnership (HIP) program, the efforts to associate the circular economy and historic urban landscape benefit from an exceptional local awareness of the urban cultural and natural heritage, permitting the elaboration of the cultural corridor concept. By using the historical river of the city, the Rječina, as a connecting line of several heritage assets leading toward the Sea waterfront, the cultural corridor represents a space of culture creation based on continuity and proximity, where all citizens can securely reappropriate dismissed parts of the city, similar to the commons' management practice. The cultural corridor has been imagined as a spatial implementation model that needs actions to be actuated. A set of actions was designed through the urban seeding process, tested in a workshop methodology, meant to address the HUL regeneration through an awareness-raising and cocreation approach by codesigning through situated learning, possible permanent or temporary actions, activities, assets to be replicated in the corridor and, per extension, in the entire city. This article will explain the way the cultural corridor concept and urban seeding were generated in the City of Rijeka, giving evidence of the motivations and the proposals made in parallel with the existing initiatives of the city and its cultural movements.

Keywords: urban regeneration; historic urban landscape; circular economy and adaptive reuse; cultural corridor; urban seeding

\section{Introduction}

Urban sprawl as a global phenomenon started in the 19th century in most European cities and immediately opened concerns among planners on the environmental and health impacts, witnessing, though recently, a stronger divide between production and consumption (especially considering the food and traditional crafting industries). Such recent urban sprawl and cities' growth had an entirely different evolution compared to their historic development until the industrial revolution, generating spots of interruption of the historic urban continuity visible both in the overall urban physical integrity [1] and in the socioeconomic tissue [2]. The city has been slowly losing its productive character, made of a combination of intangible savoir faire and knowledge for tangible commodities (i.e., shoes, 
furnishing, ironworks, etc.) corresponding to a set of jobs (and skills) that have vanished due to obvious and consequent delocalization pressures, making it more and more of a place of intangible production, as well as an enormous unconscious mouth [3]. In fact, the recent studies of the regeneration of historical areas have recognized their potentials to attract highly skilled labor [4-6], while some other theories identified historical areas as centers of regional competitiveness [7-9] in line with the Florida original and revised idea of regeneration through creative class $[5,10]$ that explicitly denounced the loss of traditional works in inner-city areas. In any case, cities lament a concentration of activities that are less and less a part of the secondary sector and more and more a part of the tertiary sector, where the creative industries are also included. The fact that, for decades, the historic centers have been losing specific traditional craftsmanship, mainly due to increasing globalization [11], has left empty spaces to be filled either by tertiary services (offices, banks, shops, etc.) or by less risky economic activities, usually requiring much less specialization (bars, restaurants, fast-food chains, automatic laundries), responding more and more to new industries, including tourism $[12,13]$. This entire process has generated an increasing distance between production and consumption, also amplified by urban sprawl, with consequences on the inhabitants' perception of the production processes. Recent research and experiences on urban regeneration have highlighted the importance of culture and creative industries $[10,14,15]$, although with parallel criticisms especially related to the gentrification effect $[6,16,17]$, boosting historic centers' renewal. Even more recently, increasing pressure on environmental sustainability has contributed to the push of the debate on urban resilience [18], on one side in light of the increasing growth globally of urban agglomerates [19], and on the other side recognizing the intense historical relationship between the "city" as a center of consumption and the surrounding landscape as a space of production [20]. This mainly led to understanding the urban areas' and historical centers' capacity to contribute to sustainability, introducing measures from basic building retrofitting to larger built-environment regreening.

\section{Literature Review}

The expansion of cities has highlighted the need to adopt new governing policies able to grasp the complexity of managing the change: a change even more threatening in European cities, characterized by dense historical layers and cultural diversity. The experiences and debates of the 1970s on historic cities have put forward the necessity to undertake integrated and holistic approaches [1,21-23], leaving behind the focus on single objects, like monuments, relics, archaeological sites, or other major/minor tangible objects in the urban tissue. It was then considered that urban areas represented "the most tangible evidence of the wealth and diversity of cultural, religious and social activities and that their safeguarding and their integration into the life of contemporary society was essential in town-planning and land development" [24], pointing out the relevance of minor, traditional and vernacular architectures. Therefore, the city "became" a coherent whole, "whose balance and specific nature depend on the fusion of the parts of which it is composed and which include human activities as much as the buildings, the spatial organisation and the surroundings" [21] (Article 3). Indeed, the question dropped on the historic city as a social, cultural and economic expression of what humanity has experienced and created over time [25]. This implied identifying the characteristics that have come to represent the historic urban form in its functions and elements, the buildings and spaces. At the same time, it became necessary to understand the overall territorial context, how the economics and the social relations have evolved, and the spatial situation in terms of superimpositions and coexistences, in line with the outstanding studies on the sense of place [26-28] and the production of space [29]. After the debates on architectural coherence within the World Heritage framework [30] and on tourism pressures [31], the international community started to consider the city again from its authenticity made of socioeconomic interactions [17], on the "atmosphere". A UNESCO initiative led to the before-mentioned notion of Historic Urban Landscape in 2011 [32], introduced as 
an international recommendation to provide guidance for more holistic management of historical and heritage areas [33-35]. Hence, the historic urban landscape approach aims to preserve the human environment's quality, enhance the productive and sustainable use of urban spaces while recognizing their dynamic character, and promote social and functional diversity [36]. It promotes the integration of urban heritage conservation goals and those of social and economic development [33]. It is rooted in a balanced and sustainable relationship between the urban and natural environment, between the needs of present and future generations and the legacy from the past. Nevertheless, the run for climatechange adaptation has moved the interests toward sustainability, somehow permitting more "relaxed" approaches versus historic areas and their intrinsic qualities, including the notions of authenticity and integrity [37-40]

\subsection{The Circular Economy and the Circular City}

Indeed, nature entered the debate strongly and in parallel with the recommendation of UNESCO in 2011. Although the international movement for environmental concern started in the early 1960s [41], the awareness of the heavy responsibility of urban areas in polluting and the consequent recognition that sustainable-culture-based urbanization is key to successful development [42] are relatively recent. The management and the governance approaches have been embracing more and more nature protection, referring to the concepts of common goods, ecosystem services and, mostly, health [43]. In urban contexts, though, dealing with heritage and historic places means dealing with the past, in a circular perspective concerning the cyclical notion of time [20], for which the future is both the recovery and the revision of the past.

Several European applied research and plans gave additional credit to the theories on the circular economy in urban contexts, receiving necessary support from the European Union in its issued policy documents and reports [44,45], that culminated in the "Partnership for Circular Economy" [46], lately confirmed by the work at an international scale by the Elle MacArthur Foundation and ARUP Associates [47,48], recognizing five major key areas, namely built environment, energy, mobility, bioeconomy and production systems in a loop [46]. Inline, the result was to consider urban metabolism [49] as the unique reference for a circular city-planning [50,51]. However, before the EU funded the Horizon 2020 project "Circular models Leveraging Investments in Cultural heritage adaptive reuse", known as CLIC, and its first findings [52,53], a direct connection between the circular economy at the urban scale and cultural heritage enhancement in the perspective of historic urban landscape was never made explicit, although anticipated in studies connecting heritage and sustainability [18]. However, the reality is that numerous examples have been feeding such a link since the 1970s (when the debate on urban renewal developed), and many more may be found in the history of architecture and city-making.

\subsection{Framework}

Understanding the notion of "circularity", taking inspiration from the autopoietic natural capacity [54] and projecting it into the urban economics perspective permits us to imagine new-sometimes imitating old-forms of governing, minimizing waste and making the most of resources, but mostly favoring the achievements of the objectives of integrated urban conservation. The recent trends that have put the circular economy at the core have opened interesting economic and cultural scenarios that may help "preservation" to not be considered as a burden. Suddenly, the old dynamics that have generated historic cities become important again, and there is a run in giving back to the built environment its partly (or even wholly) lost integrity and authenticity as applied to cultural heritage. Even tourism contributes to this trend by developing new models based on experience, balanced judgment and taste.

However, the connection between cultural heritage preservation and the circular economy is still not thoroughly investigated, although the doctrine of preservation talks about it as a rooted concept $[55,56]$. In particular, beyond the most apparent achievements in 
building retrofitting (which is unfortunately heavily impacting historic environments) and good studies on the circular economy and the building sector [57], the circular loops have to be introduced in other domains of historic city management, ranging from craftsmanship revitalization to circular-activity promotion and governance [52,58], insisting on the need to promote innovative businesses and coordinating actors to make the city an efficient and citizen-oriented machine that is increasingly limiting its consumption.

As recent studies have highlighted, [46] urban metabolism and the circular economy may generate additional interest in port cities, where infrastructural and productive facilities developed in or in the proximity of inner-city cores throughout the 19th and 20th centuries. Challenging applications increase significantly in locations characterized by convoluted geomorphology: important historic-cultural layering, intense industrial expansion, frequent changing socioeconomic dynamics and extremely fragile ecosystem equilibria that ask for the reintegration of historic harbor facilities in the urban systems in their physical, social, cultural and economic components [59]. In Europe, from the Italian Genova and Trieste to the Spanish Valencia and the Portuguese Lisbon, the examples are many: among them, the city of Rijeka in Croatia, where the degree of complexity increases for the incomplete transition from the former socialist order to a more contemporary liberal governing model, which started in 1995 after the break with the former Yugoslavia.

\section{Materials}

\subsection{Cultural Richness in the History of Rijeka}

Rijeka was always considered an attractive living spot due to its outstanding strategic location, generating interests in time and space. Presence in the area already were registered in the Palaeolithic and the Neolithic, although the first settlements, with foundations of the prehistoric castles that served the protection of the bay also during the Liburni, date back to the Bronze and Iron ages. It was during the antique Roman period that the city developed on a lower level, closer to the sea, on one side of the Rječina River. The historical sources and their revision [60] narrate a later dual medieval settlement, one called Tersat on the upper part of the hill, still present as the main attraction of the city, and another lower city, surrounded by stone walls and towers on the previous Roman city site, that took the name of the Reka (in Slavic language), lately Rijeka (in Italian, Fiume) for the presence of the river.

For centuries, the city developed as a port under different rulings, transforming its economic richness into cultural progress (Figure 1), as the first printing house using Glagolitic, the alphabet the Croatians adopted early on, demonstrates.

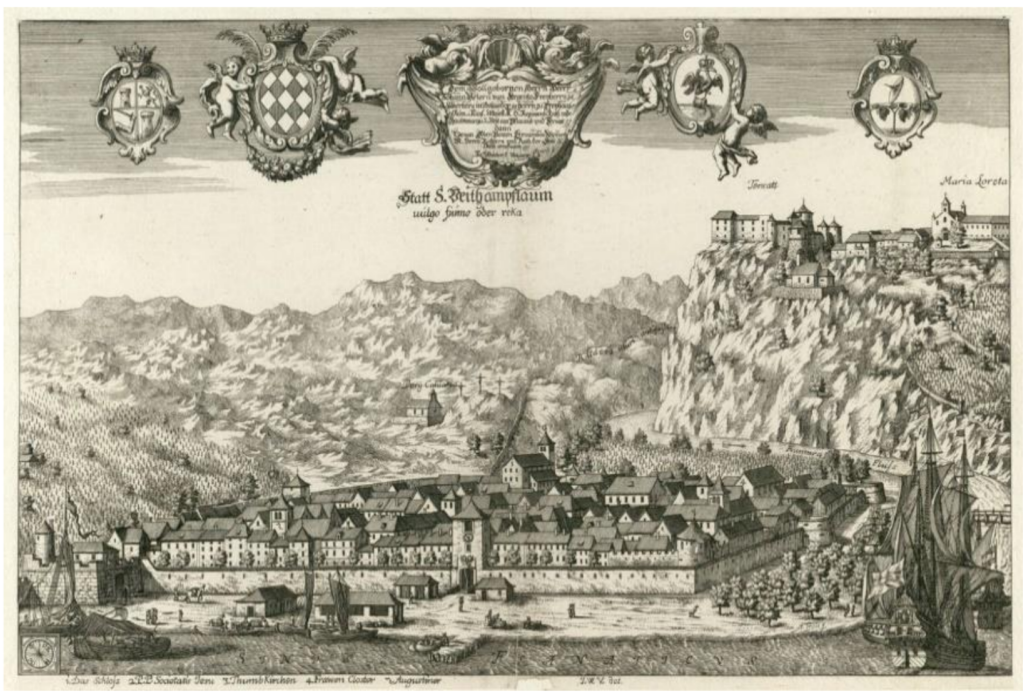

Figure 1. Reka/Fiume and Tersat in 1689 as depicted by Valvasor. 
Finding its highest expansion during the Austro-Hungarian period from second half of the 19th and beginning of the 20th centuries increased the entire region's infrastructures. This period brought to Rijeka enormous progress, evident also in the surrounding Kvarner, with the expansion of important tourism centers like the Opatijska Riviera and the towns of Opatija and Lovran, and in infrastructures, industries and urban-organization actions that are today part of the cultural landscape of the gulf; besides, architecture and built environment shaped an entirely new landscape. In this period, important landmarks and exceptional events happened for the city, such as the establishment of the Royal Hungarian Navigation Company "Adria", the construction of the paper mill in the Rječina, the construction of the first torpedo factory [61], and the establishment of the first industrialscale oil refinery in Europe. The population expanded drastically, and Rijeka was among the main Mediterranean ports of the period until World War I. The end of the war opened the so-called "Fiume Dispute" that left traces in the society for the entire century [62-64]. Years of contention between Italy and the Kingdom of Serbs, Croats and Slovenes came, culminating in the World War II period when Rijeka openly acted in the anti-Nazi and antifascist front. From the end of World War II and the establishment of the Socialist Federative Republic of Yugoslavia, Rijeka maintained its image of an open and tolerant city, facing the new system's changes as a major port of the new state. Investments were made to increase the city's industrial production and enlarge its harbor, reinforcing traditional industrial activities such as paper production, naval construction, refineries, textiles, hydroelectric and thermoelectric power plants, etc. Such an increase gave an entirely new character to the urban agglomerate, making it the symbol of the cultural, industrial society of the Socialist Federation.

Today, Rijeka counts approximately 200,000 inhabitants [65]. It is working to manage a vast heritage ranging from tangible to intangible, from social to political, aware of the importance of all the historical layers and presences, seeing diversity as a potential to reinvent a city that can no longer count on the traditional industry. Following this direction, the city's efforts were rewarded with its naming as the European Capital of Culture in 2020, which unfortunately did not generate the expected positive externalities due to the recent, well-known COVID-19 pandemic.

In line with the cultural and historical layers of the city, as well as with its achieved image of an open city, the European Capital of Culture 2020 strategy and program choose the theme Port of Diversity, thus leveraging the history of diversity and cultural coexistence of the largest Croatian port. Focusing on the capitalization of the local culture and cultural heritage, the city invested in creating new cultural infrastructure, paying particular attention to the social dimension, and considering culture as one of the main urban and economic regeneration tools.

\subsection{The Spatial Context of the City}

To have full enjoyment of the new cultural urban life, Rijeka is aware of the need to regenerate is spatial context, made of natural and infrastructural assets that were partly taken aside by the heavy industrial and port developments. In particular, its outstanding natural beneficial water presence guaranteed by the sea and the river, but which are not fully accessible by citizens. The seafront, occupied by the port facilities, warehouses and docks, is separated from the current city life, and in most areas, space is occupied by legal and illegal parking.

Additionally, the connection to the Rječina River and its old basin of today's Dead Channel is not easily perceivable due to traffic and street junctions. Also, the riverbanks are not maintained and not accessible in most parts to the citizens. Rječina springs about $18 \mathrm{~km}$ north of Rijeka, having a powerful and torrent stream, and makes its way through the scenic canyon, where it reaches the city near Školjić. In the past, the area was a bay and early port, and Rječina exited the canyon here and drained into the Adriatic Sea. The river deposits formed small fertile planes. The biggest river alluvium was called Školjić or 
Scoglietto. Gradually the alluviums were backfilled, and the city area expanded toward today's Delta.

\subsection{The Strategy of Rijeka and CLIC}

The participation of Rijeka in the CLIC project signified a step toward the city's current policies of sustainable redevelopment, with emphasis on cultural capital and the need to foster creative industries. The urban strategy [66] insists on a knowledge-based society and the intense participation by all citizens to strengthen social inclusion and commonly chosen projects, to enforce the city's mission to foster openness, tolerance and civic responsibility. In particular, the third strategic axis focuses on enabling the dignity of all citizens by strengthening social inclusion and developing projects of common interest; namely:

Urban regeneration:

Integrated urban planning;

- Candidature for the European Capital of Culture, finally achieved; and

- Construction of city infrastructure.

- Protection and improvement of the quality of life and citizen health:

- Creation of conditions for an independent life for young people;

- Health protection and improvement (educational and health programs, sports, recreation);

Modern social policy; and

- Creation of conditions for independent work for young people.

The scenario for testing the circular economy seems particularly fertile, on one hand because the city's cultural heritage, in particular its industrial heritage, is outstanding, with numerous assets in needs of reuse and recontextualization; and on the other hand, because the social dimension in the circular economy is fundamental, considering that what is mainly required is a new narrative of waste, a new mental set toward the use of resources and spaces. In addition, the traditional attention of the city to the quality of life, probably enhanced by the favorable climatic conditions, the presence of the sea and the strong regional tourism destination, as well as education at all stages, with focus on early years, made the target of CLIC particularly suitable for the application.

The CLIC project, aware of the need to move from a monument centered on a historic urban landscape approach, asked cities to define some initial case studies. The City of Rijeka proposed three cultural heritage assets already identified in the development plans of the ECoC 2020. The initial case studies were (Figure 2):

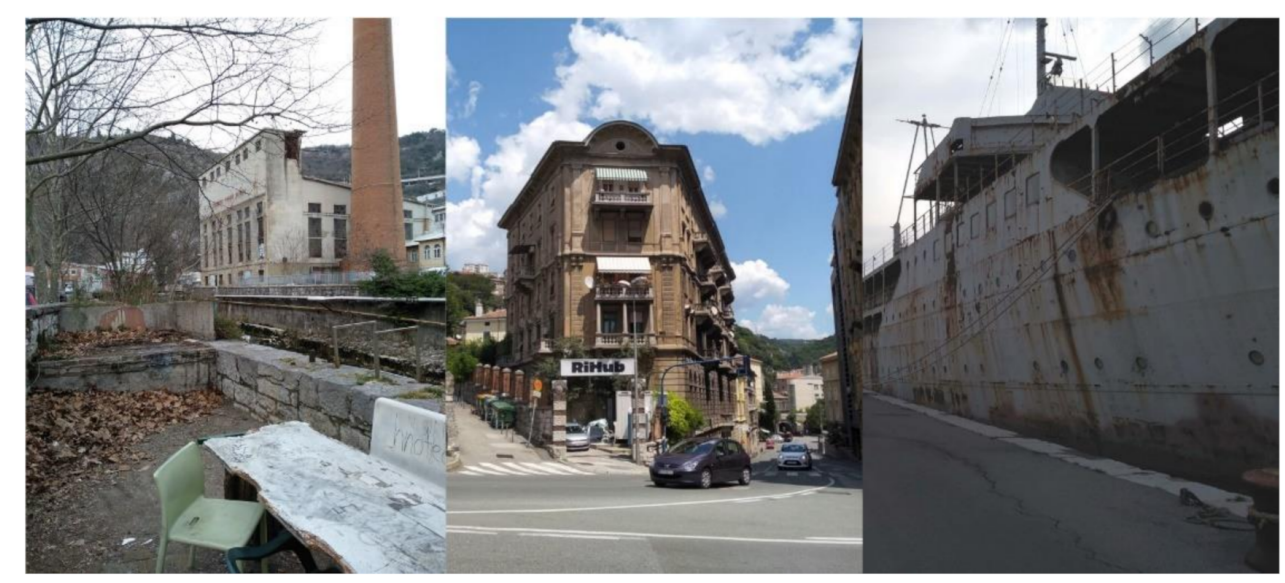

Figure 2. The three main assets chosen for the CLIC project by the City of Rijeka. From left to right: Energana, Rihub and Galeb. Photo credits: Marco Acri. 
- RiHub [67], located on the northern edge of the city center. RiHub is a multiuse collaborative space in a former tissue factory, aiming to become an incubator of the creative city, integrating the programs by empowering a community through civil initiatives and becoming a platform for active citizenship.

- The Galeb Ship [67-69], a key symbol of Yugoslav socialist iconography, is a national monument for having been used as diplomatic residence by the former Yugoslavian president Tito. After the restoration and refurbishment into a museum, restaurant and hostel, the Galeb will be moored on the Rijeka's Breakwater Molo Longo, guaranteeing regular visits.

- The modernist building of the Energana power plant of the paper-mill factory Hartera was built in 1931 as the most modern electric center, with a steam turbine that generated 3200 horsepower and modern installations. Its adaptive reuse envisioned creating an incubator of cultural and creative industries (CCI) and ICT industry through European Cohesion funds.

- In a second stage, the City of Rijeka also included the new cultural complex in Benčić, a former industry $[67,70,71]$ currently under renovation and reconstruction, that will host various cultural institutions (museums, library, children's house), presently scattered throughout the city. The program intensity in the Benčić complex will have a positive mutual benefit and encourage an existing offer of permanent and temporary services.

- An additional asset, characterized by proximity to the city center and the Delta, is the Exportdrvo's large industrial warehouse, which has the spatial and logistic potential to host a diverse program of ECoC 2020, such as expositions, concerts and festivals indoors. Such potentials encouraged the Port Authority and the City of Rijeka to begin the hall refurbishment and dedicate it to the citizens' use [72].

Beyond the intrinsic qualities of the cultural heritage assets that were asking for specific attention in their adaptive reuse, specifically for their authenticity and integrity, the challenge in Rijeka was to generate a spatial connection of the heritage assets, adopting a more landscape approach that could include different inputs from the lessons of the circular economy. Such connections are difficult to achieve due to the multiple existing spatial and mental obstacles for the city center's full use (full assets shown in Figure 3).

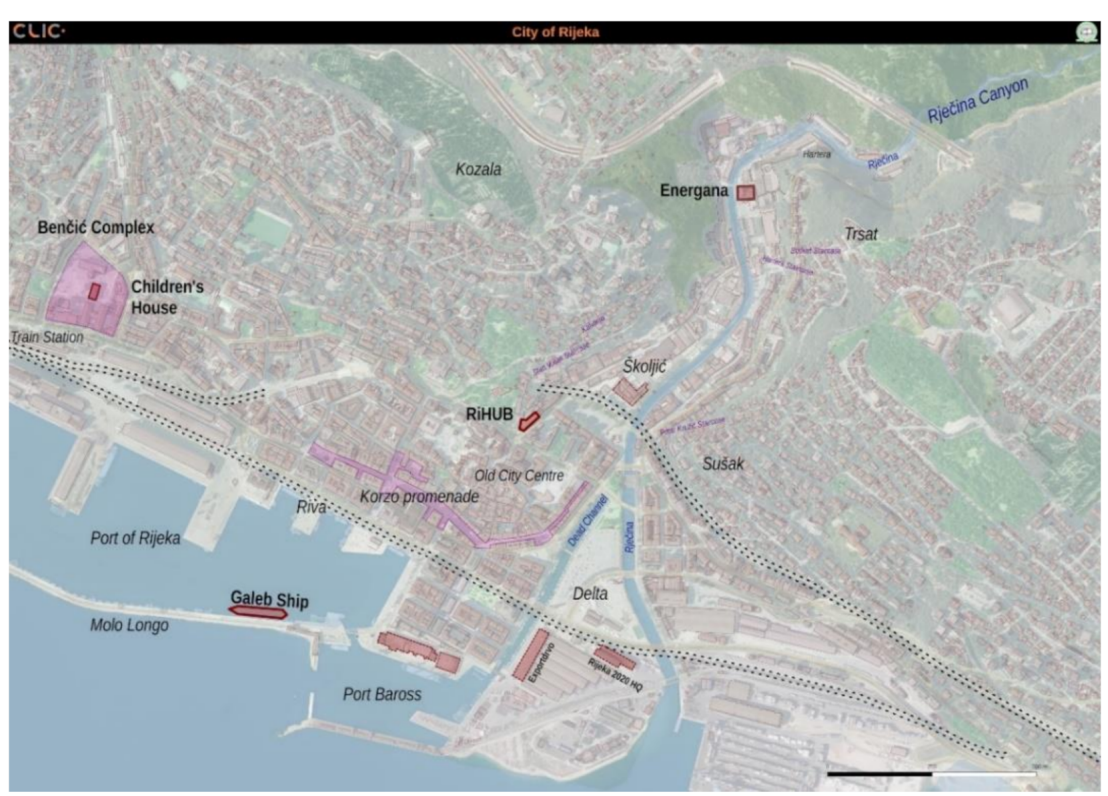

Figure 3. The identified cultural heritage assets in the city center. Map credit: Maja Debevec. Cartographic data: City of Rijeka, 2018. 


\section{Methods}

\subsection{The Cultural Corridor}

As anticipated, the methodology to be adopted in the CLIC partnership to codesign potential action plans to actuate circular-economy principles in cultural heritage redevelopment contexts has been named HIPs, or Heritage Innovation Partnerships. The idea behind this methodology, explained in other articles on this issue, is to build innovative cooperation initiatives among the local stakeholders meant to successfully regenerate cultural heritage through a circular economy [73]. This means imagining new forms of restoration and regeneration processes, new businesses and new governance models. In fact, one of the main results of the HIP process in each local case study was to codesign and possibly coimplement action plans to be integrated into present urban strategies, respecting their urban and cultural landscape in a territorial perspective $[18,20,46,56]$. The structure of the HIP process was conceived in five main meetings.

The first meeting focused on perception-mapping, a methodology introduced in urban heritage studies and applied in all the CLIC partnership cities [74], namely Salerno, Rijeka, the Vastra Gotaland Region and Amsterdam. In a closed meeting following a local survey of citizen interviews carried out in the city through the same principles by a student from the business school in Brussels (ICHEC), attending stakeholders were asked to indicate the cultural assets of the city according to five senses. This long exercise enabled a new form of practice in the city, generating new maps of additional values that could not be grasped by simple expert literature-based research. The findings, although limited by the available time and restricted number of participants, gave an important depiction of the in-depth knowledge of the inhabitants of Rijeka about the history, the tangible and intangible cultural heritage, the perceived needs and expectations, and the well-known social attitude toward openness, tolerance and sharing. Such findings are briefly presented in Table 1 below, divided per cultural heritage to be enhanced, cultural heritage to be used and spatial-integration needs.

Table 1. Results of the perception-mapping and first questionnaires from the first meeting held by ICHEC. Credit: ICHEC.

\begin{tabular}{|c|c|c|}
\hline \multicolumn{3}{|c|}{ Combined Proposals (Questionnaires and Workshop) } \\
\hline Cultural Heritage to be Enhanced & Cultural Heritage to be Used & Spatial-Integration Needs \\
\hline Rječina River and the landscape. & Reopen the former city beach. & $\begin{array}{l}\text { Remove the parking area of the } \\
\text { bus company. }\end{array}$ \\
\hline $\begin{array}{l}\text { The connection route from the city center } \\
\text { to the paper factory and the watermills } \\
\text { (along the river). }\end{array}$ & $\begin{array}{l}\text { The ship buildings and the waterfront } \\
\text { (between Delta and Molo Longo and } \\
\text { between Žabica bus station and the train } \\
\text { station) belong to the port company, and } \\
\text { it is an off-limits area for the citizens. }\end{array}$ & $\begin{array}{l}\text { Expansion of the pedestrian zone (or } \\
\text { create new pedestrian zones) to the Delta, } \\
\text { the waterfront and the Benčić. }\end{array}$ \\
\hline $\begin{array}{l}\text { Delta and the waterfront along Riva } \\
\text { street are parking and storage at present; } \\
\text { these areas should be reused and open to } \\
\text { the public. }\end{array}$ & $\begin{array}{l}\text { Zamet cave is not well-known by } \\
\text { the public. }\end{array}$ & $\begin{array}{l}\text { Landscape design at the Benčić and } \\
\text { injunction of more green space in the city } \\
\text { center and the Delta area. }\end{array}$ \\
\hline $\begin{array}{l}\text { Molo Longo and the port cranes (new } \\
\text { facilities, more activities and } \\
\text { cycling/walking path). }\end{array}$ & $\begin{array}{l}\text { Cemetery KOZALA is not well-known to } \\
\text { the public }\end{array}$ & Digitalisation of the old city centre. \\
\hline $\begin{array}{l}\text { The public spaces and squares, including } \\
\text { the Delta area and the square in front of } \\
\text { the Nikola Tesla Elementary School. } \\
\text { More facilities and green space. }\end{array}$ & Revitalize the fishing activities. & $\begin{array}{c}\text { Revive the story of Rijeka as a historical } \\
\text { industrial leader. A museum about } \\
\text { industrial history might use the former } \\
\text { paper factory. }\end{array}$ \\
\hline
\end{tabular}


Table 1. Cont.

\begin{tabular}{|c|c|c|}
\hline \multicolumn{3}{|c|}{ Combined Proposals (Questionnaires and Workshop) } \\
\hline Cultural Heritage to be Enhanced & Cultural Heritage to be Used & Spatial-Integration Needs \\
\hline $\begin{array}{l}\text { Traditional meals: -BAŠKOT, polenta, } \\
\text { Ribice and Rapska tora, Rabska torta. }\end{array}$ & Local boats and Kalafati craftsmanship. & $\begin{array}{l}\text { Valorize people's ability and freedom to } \\
\text { be authentic. }\end{array}$ \\
\hline $\begin{array}{l}\text { Protect the water resources and increase } \\
\text { awareness of them. }\end{array}$ & $\begin{array}{l}\text { Conservation project for the covered } \\
\text { mosaic square. }\end{array}$ & Protect some buildings. \\
\hline $\begin{array}{l}\text { Regenerate all the green parks (mlaka, } \\
\text { delta, Trsat, nature history museum ... ). }\end{array}$ & $\begin{array}{l}\text { Revitalize the unknown cuisine in Ivan } \\
\text { Kobler square. }\end{array}$ & $\begin{array}{l}\text { The dilapidated warehouse area near the } \\
\text { train station and some unused industrial } \\
\text { buildings along the Rječina river might } \\
\text { be delisted. }\end{array}$ \\
\hline $\begin{array}{l}\text { Enhance the Dominikanski samostan } \\
\text { (Domnican Convent). }\end{array}$ & The theatre Fenice should be reused. & $\begin{array}{l}\text { Ticketing for tourists at Trsat castle, but } \\
\text { keep it for free for locals. }\end{array}$ \\
\hline $\begin{array}{l}\text { Kiša umbrella - designed locally and } \\
\text { related to the local climate. }\end{array}$ & Reuse the warehouse near the waterfront. & $\begin{array}{l}\text { Revitalize the Hartera music festival and } \\
\text { envelop the local music (rock music). }\end{array}$ \\
\hline The Galerija Principij. & & $\begin{array}{l}\text { Remove the old Žabica bus station and } \\
\text { build a new one near the Delta } 5 \text {. }\end{array}$ \\
\hline \multirow[t]{11}{*}{$\begin{array}{l}\text { The conservation project and the regular } \\
\text { maintenance of the heritage and } \\
\text { historic buildings. }\end{array}$} & & New great concert hall. \\
\hline & & Žičara-Trsat network (cablecar). \\
\hline & & New cycling routes cross the city center \\
\hline & & Zipline to Trsat castle. \\
\hline & & New religion museum. \\
\hline & & $\begin{array}{l}\text { Remove the PVC advertising in the old } \\
\text { city center. }\end{array}$ \\
\hline & & Metro railroad. \\
\hline & & $\begin{array}{l}\text { New community or cultural center for } \\
\text { citizens and diversity groups. }\end{array}$ \\
\hline & & $\begin{array}{l}\text { Improve the communication of the public } \\
\text { and participation possibilities. }\end{array}$ \\
\hline & & $\begin{array}{l}\text { New international platform can increase } \\
\text { the attractiveness of the city. }\end{array}$ \\
\hline & & New multimedia library. \\
\hline
\end{tabular}

Beyond the interest in the regeneration of many cultural capitals of the city, participants indirectly defined a distinct area of the city around Rječina and close to the present inner core where people expect to have a greater urban experience. Such expectations, merged with the awareness of a more sustainable city's needs, constituted the basis for the future meetings, in which planning ideas inspired by the circular economy were proposed.

The following two meetings were then organized with the following reference topics:

1. Debating cultural heritage adaptive reuse while respecting the concepts of authenticity and integrity, in line with the most recent trends in conservation [75];

2. The connection among the selected objects to be regenerated, namely the Galeb ship, the Rihub center and the Energana power plant;

3. The establishment of new tools or systems to respond appropriately to the historic urban landscape approach while taking advantage of the new inputs from the circular economy and its impact on environmental enhancement [76];

4. Provide better living environments for the citizens and the visitors; and 
5. Imagining forms of businesses to respond to the increasing unemployment of the urban area.

Thanks to stakeholders' increasing awareness of the circular city principles [48], a possible new local action plan to integrate the city larger spatial policy was drafted and presented to the city administration in July 2019. Such an action plan consisted of four main axes of intervention, with four associated general objectives, namely:

- Regenerating the Rječina River, as a core asset in the historic urban landscape of the city, jointly with the sea and the waterfront;

- Promoting the slow use of the city, counting on the historic urban landscape regeneration and the inspirations from the circular economy, with attention to new businesses and new employment forms;

- Enhancing the city cultural heritage in its tangible and intangible components; and

- Improving the internal and external accessibility of the city, in particular reducing car use and pollution.

Such general objectives produced specific objectives and potentially related actions for their medium- and long-term achievement, with a detailed mapping of influential stakeholders. Several conditions in the process seemed to have contributed to identifying a specific area of the city, already observed after the perception-mapping method, as the most attractive both for its historical and cultural capital and as a common pool resource [77,78]. It is the area along the Rječina River, towards the Delta with the Dead Channel, including a significant part of the city waterfront. This area is rich in terms of cultural layers and natural resources, but extremely fragile in terms of heritage capital $[73,79]$. Thinking about the circular loops and recalling the corridor's concept as enabling infrastructure, a new conceptual model based on the historic urban landscape approach was introduced, called the Cultural Corridor.

\subsection{The Cultural Corridor Model}

From a landscape perspective, the selected area could have acted as a spot of suspension, of testing, of mending, of creative thought. Corridors are usually intended as paths for privileged flows of things and/or living beings (ecological corridors, humanitarian corridors, etc.). They act like axes to facilitate access and safe and continuous movements of users by adopting a straight line; their design is homogeneous, continuous and isotropic, involving the cause, the interval, the effect or the subject, the distance, or the object of observation [80]. On the other hand, corridors do happen, also spontaneously, when systems that are in relation result as unconnected, they act for lace-making, namely to achieve the making of relations. The history of the built environment has experienced different forms of corridors, as main pedestrian streets to stroll and trade, as humanitarian strips to preserve the safety of groups, and as ecological connections to guarantee the conservation of ecosystems in fragmented landscapes. As an additional dimension, they can be seen as areas of integration, of cohabiting, and of sharing, while still keeping their dimension of "safety". There are many examples of infrastructures that do overcome the obstacle and permit faster connection but act as an authentic place where people and things stop, and the dynamism of movement gains another dimension. People still move, but differently: Ponte Vecchio in Florence or Rialto in Venice, or Passages in Paris are both the shortcoming and the places where people stop to exercise different social dynamics [81]; places where time is partly suspended, and the rest may take advantage.

The Cultural Corridor model in Rijeka, therefore, aims at generating an ideal space where the quality of life is searched through heritage preservation and valorization attention by means of the circular economy. It needs to build up different circularity scales: the urban/territorial scale, building/object scale and social/community scale, which do translate into actions and businesses. The transformation is achieved by fostering adaptive reuse of cultural heritage buildings, redesigning and revitalizing the urban depleted areas, enhancing the use-cycle maximization of building stock and continuity of settlement while 
protecting the local, territorial identity's enlarged community. Social capital and innovation can be used as a motor to transform and cocreate the area through a participatory process, using cultural and social activities that may turn into comanagement (or comonitoring). The corridor's model consists of defining a working regeneration area entirely dedicated to citizens' cultural life that is fully available, usable and characterized by codesign, cocreation and integration of uses. Therefore, implementing the Cultural Corridor enables citizens to reappropriate dismissed parts of the city by highlighting the need for multiple-layer intervention, including strategic planning and the bottom-up acting applied by sharing and learning by doing, through a situated learning process [82].

\subsection{The Implementation Process of the Cultural Corridor Model in Rijeka}

The Cultural Corridor for Rijeka is an integrated urban spatial system and a model for regeneration, meant to be a paradigm for a new sustainable use of inner cities and urban deprived areas, adopting the culture and cultural heritage enhancement as a cross-leading principle for the adaptive reuse of infrastructures, buildings and urban voids. In Rijeka, it has been conceived as a connecting area in a circular movement, from the Rječina canyon to the urban waterfront, and in return, including important historical areas that characterized the historical development of the city along the centuries, as:

- The Molo Longo, the breakwater of the city port reaching to the center, presently one of the main attractions for residents for weekend strolling and jogging;

- The Galeb Ship, for years located in Port Baross, will after the renovation be moored in the central harbor;

- Port Baross itself, hosting impressive modernist architecture presently underused, but holding an exceptional location in the real estate of the city;

- The Exportdrvo warehouse, one of the main wood exporters in the former Yugoslavia, today partly in use as multifunctional space and depot;

- The Delta area, an exceptional plot of land between the two inner canals, presently underused as urban main parking area;

- The Rječina River and Dead channel, the two watercourses, completely underused contrary to the past;

- The Školjić Area and industrial complexes by the inner Rječina area, including the Energana and Hartera facilities, presently partly abandoned and avoided by residents; and

- The historic city center, including the main city market, the Rihub center, the former Školijć pool and the Archaeological park Principium, the Tarsatica period Mosaics, medieval historic city walls, and many more are daily suggested for an integrated HUL policy.

In a second phase, the Benčić complex in the western part of the inner-city center, presently undertaking important redevelopment activities to create a cultural and museum district, also is to be included, absorbing the present main street and pedestrian area, the Korzo. Users will have spatial and functional continuity throughout the city without interruptions in terms of cultural intensity and historic urban landscape.

The corridor (Figure 4) has been designed as a field practice, meant to plan, implement and test the circular principles and eventual experimentations to connect them with the City of Rijeka's current good practices. It is considered as a space of "mending" the urban tissue through cultural practice, both in the built environment and in the fields of knowledge and craft development. In the corridor, small-scale interventions are accompanied by an integration of uses in a way to permit present and new users to engage in a comfortable, creative and inspiring sustainable use of the city, in which the use of culture gives the sustainability dimension, as such by definition [42]. Inside the corridor, different urban regeneration tools have to be respected, being in line with the most modern urban-conservation trends, including essential considerations on authenticity and integrity that guarantee the respect of uniqueness and genius loci in any historic area. 


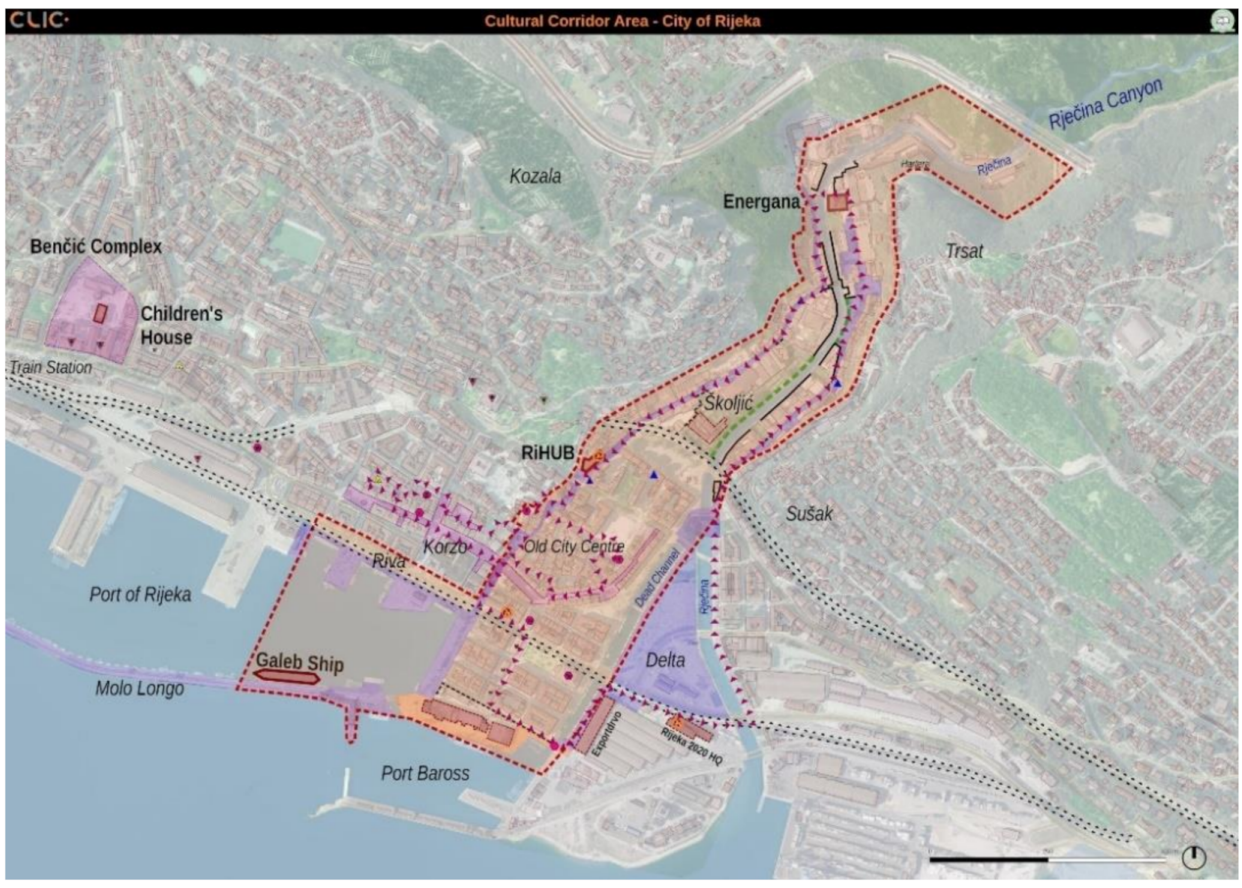

Figure 4. The area of the Cultural Corridor in Rijeka. Map credit: Maja Debevec. Cartographic data: City of Rijeka, 2018.

\subsection{The Characteristics of a Cultural Corridor}

The revitalization of the area within the historic urban landscape of the city through a cultural corridor is therefore allowing community-led and planned micro-urban actions and interventions in line with circular models, addressing public urban and green areas, as well as vacant premises on the city parterre (ground floors) - replanning urban deprived areas and redesigning depleted cultural objects in the urban landscape, hopefully hosting well-integrated and coordinated innovative circular activities. At the same time, it is meant to host new activities enabling the area's attractiveness (in terms of citizen use) and the creation of new sustainable employment opportunities raised by the circular economy.

As such, it should include:

- A safe and inspiring environment;

- A multifunctional human-centered area;

- A space of exemplary interventions on cultural and natural heritage preservation and valorization;

- A flexible room for innovative initiatives on sustainable living;

- A leisure space, healthy and welcoming, and thus without vehicles and consequent pollution, hosting green and cultural events.

- Proximity and integration of the cultural offerings, hopefully in a multifunctional concept.

As a model, for its implementation, tools are necessary. Tools can be many, different and involve different actors. They could be top-down, as awareness-raising policies, regulations, economic incentives, infrastructural interventions and governance mechanisms, as well as bottom-up, guided by local individuals and NGOs or universities, meant to inspire, test and experiment, also in temporary forms.

The preconditions for a Cultural Corridor are the definition of a flexible boundary around rich and underused cultural and natural heritage, the imposition of integrated and complementary circular activities, and openness to circular initiative testing. It is important to stress that the corridor is meant to equally attract all segments of the society, with the awareness that circularity is also a social concept, beyond its traditional economic meaning. In addition, as seen in the case study, a Cultural Corridor must be characterized 
by slow mobility, low pollution, high eco-systemic conditions and diverse cultural practices, possibly aligned with the genius loci [83] and history of the place. For what was experienced in Rijeka, the steps to follow were:

- Mapping of assets (territorial, cultural, natural, tangible, intangible), and their prioritization and potentials;

- Enhancement of urban accessibility and connectivity of the selected heritage places;

- Codesign and cocreation with the stakeholders and local community of the integrated regeneration; and

- Fostering the social and cultural creative activities and initiatives within the area of revitalization.

In the case of Rijeka, a bottom-up tool for the implementation of the corridor was designed and only partly tested due to the COVID emergency; it has been called Urban Seeding.

\subsection{Urban Seeding}

Given the cultural corridor as a model for implementing circular-economy principles in highly culturally dense inner-city areas to be regenerated, and that such space can be assimilated for its landscape dimensions into a common pool resource, the participatory practice is essential. Effective participation in the cultural landscape can be performed as a "care" practice by the heritage or aesthetic community [84,85], with the results of boosting awareness and creating conditions for shared stewardship. This is indeed the principle behind the common pool resources, as carefully described in their sustainable-management operability by Ostrom (2010). Under common precise and shared rules in a defined area, with specific penalties for transgressors, the "community" takes the lead. In Rijeka, to permit the corridor's integrated, eco-systemic growth, a specific coplanning and comonitoring tool was necessary. However, this could not come from scratch-from a simple aggregation of enthusiasts and individuals-because the heritage preservation dimension, and thus the "supervision" level, was fundamental. In this specific case, it has been considered appropriate to engage enthusiasts in groups with interdisciplinary-planning knowledge and through mentoring supervision to introduce a circular economy's main concepts, historic urban landscape and sustainable urbanism, with particular attention to integrity and authenticity.

Conceived by the University of Nova Gorica (UNG) and the City of Rijeka, and implemented with the support of the University of Rijeka (UNIRI) and the DAR-Association of Architects of Rijeka, Urban Seeding is a sociocultural and planning tool, based on spatial experimentation and on multistakeholder inclusion, envisaged as a versatile and dynamic process. It acts as a catalyst for revitalization by the systematic step-by-step coplanning, codesign and implementation of urban low-cost and small-scale interventions, which for the occasion are called Urban Seeds. Densification and replication of such seeds and diversification of offered programs and actions would "attract people to use" space.

Urban Seeds are small local urban interventions or actions providing the community's activation through a diversity of use, programs, actions and events that are specifically meant to enable attention. Indeed, the design and quality of space can be easily perceived and performed by specialists, while nonspecialists and common citizens may need examples to familiarize themselves with the aesthetic dimension of heritage. Based on the idea of continuity, temporary initiatives may gradually become recurrent or permanent installations, actions or events in the urban and green areas and vacant premises of the city parterre. The concept focuses on sprouting these microinterventions from the local needs. Though the Urban Seeds address the spatial context and its heritage through the circular economy's principles, the generalized idea is to be inspirational and replicable elsewhere, focusing on the landscape (urbanscape) approach. 
An additional dimension of Urban Seeding is learning-by-doing, which mostly expresses the need to confront with an asset in the area. Actors of the seeding must point out the need, codesign it through interdisciplinary debates and generate ideas that have to be aligned with the sustainable circular city and stimulate the local culture and/or promote the cultural-heritage valorization. This also means the ideas may or may not be successful, so they are called seeds for their uncertain growth, and the seed idea stems partly from the concept of the tiny or "Miyawaki" forest [86].

As per urban living labs and communities of practice, individuals with different backgrounds can jointly work together for a specific purpose, thus giving their expertise and knowledge for others' use [82]. This condition is essential in the Urban Seeding in Rijeka; however, given that the final focus of the Urban Seeding is contributing to the achievement of the Cultural Corridor model, it was essential to suggest groups of "individuals" with specific skills to share them and foster a strong interest in participating, far beyond simple enthusiasm. In fact, a successful factor of the seeding was the long-term commitment or potential self-interest in the development of the initiative, which, in the case of the Urban Seeding in Rijeka, was an employment opportunity, improvement of the future residency and career achievement.

In fact, stewardship is another important concept in the urban-seeding process. As the Cultural Corridor can be seen as a declination of common pooled resources, self and/or community monitoring is fundamental. Any seed's success highly depends on its main actors' capacity and capability to monitor, promote and protect the tangible or intangible results.

The establishment of an urban-seeding process in Rijeka asked for the following steps (although the COVID-19 pandemic had a severe slowing impact):

- Select the specific urban areas to be redeveloped. The initiative can emerge from different actors: city, local city boards, citizens or other organizations' initiatives. In the case of Rijeka, the Cultural Corridor was the testing and target area;

- Compose a more multidisciplinary group of players with professional and personal interests in the redevelopment of the area (economists, planners, artists and designers, ecologists, tourism and hospitality experts, etc.) and other interest groups (history, heritage, tradition and craft specialists, artisans, etc.), as well as stakeholders to be included in the process;

- Define the leading role and/or tutorship for the working groups;

- Introduce the leading concepts of the area development, namely for the Cultural Corridor, cultural heritage adaptive reuse, circular economy and historic urban landscape notions;

- Organize the groups' site visits to critically assess the spatial context and offer the participants a discussion platform. This step is fundamental to get participants to experience the area, even though they already are familiar with it. The essential focus of this step is reminding them, onsite, of the purpose of the redevelopment idea (circular economy; cultural heritage reuse and redevelopment);

- Organize the groups' workshops to work on the topics, provide expertise and examples if needed, and consult with relevant stakeholders to obtain consensus and / or advice on permissions, existing plans and possible integrations with existing programs; and

- Commit to the final spatial integration of ideas of selected feasible and implementable projects. See Figure 5 for the organization of the seeding. 


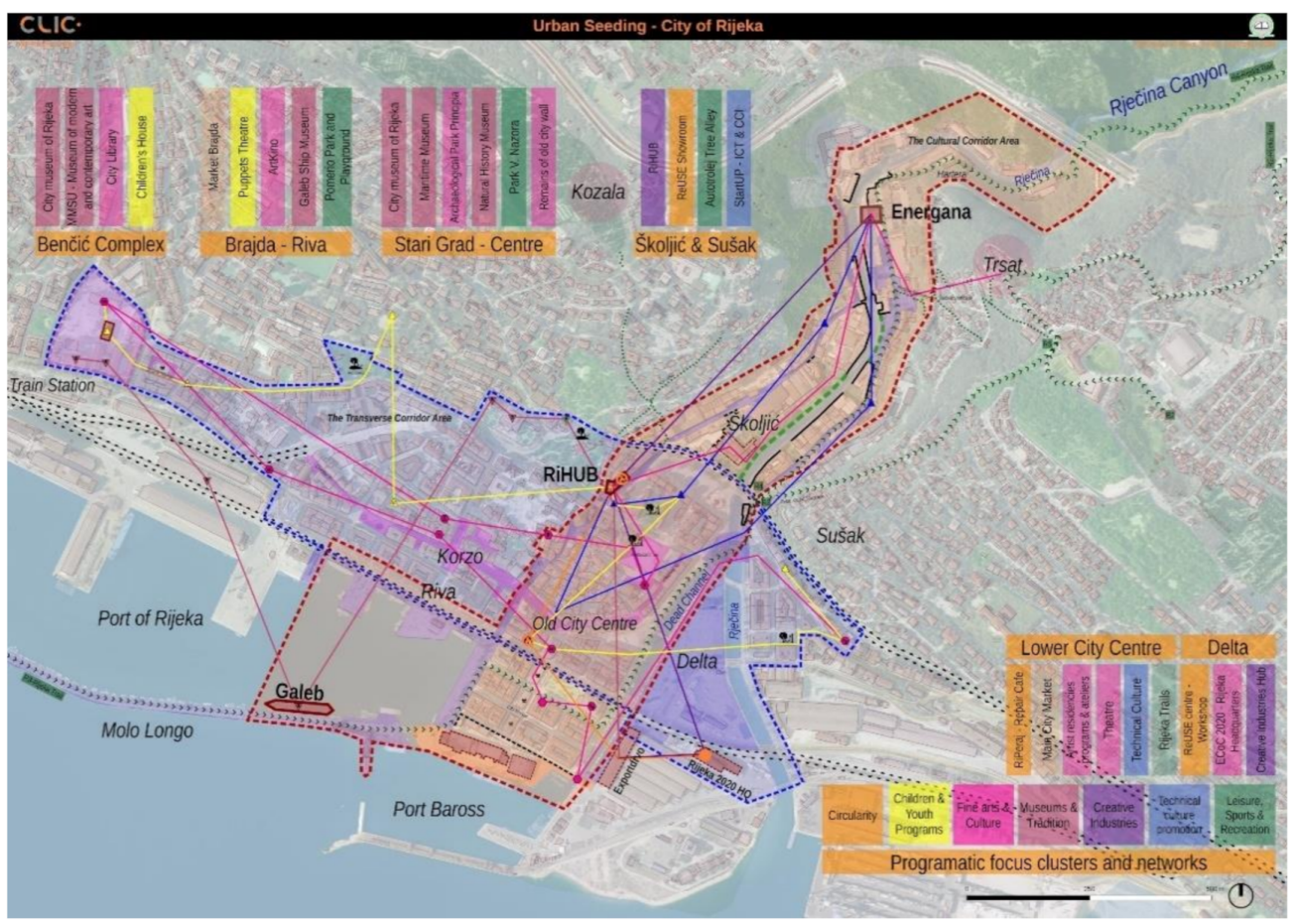

Figure 5. The area of the Cultural Corridor with HIP process results and an Urban Seeding focus. Map credit: Maja Debevec. Cartographic data: City of Rijeka, 2018.

\subsection{The Urban Seeding Workshops in Rijeka}

The Urban Seeding process was developed by UNG and UNIRI, selecting up to 30 participants with different backgrounds to compose multidisciplinary groups. However, participants:

- Did not have specific knowledge about cultural heritage conservation and protection. None of them had a specialization in the field, given that this is not yet a welldeveloped field of study in the country;

- Did not have specific knowledge about the historic urban landscape approach, and this must be connected to the previous point, as well as to the relatively small tradition in the country to deal with historic urban areas through integrated approaches. This may depend on the relatively short life of Croatia as an independent country; and

- Did not have specific insights into the circular-economy theory. If it is indubitable that younger generations have already developed an intense environmental sensitivity, this does not mean that this is logically and theoretically transferred to individual research.

These important preconditions were asking for a consistent content provision from the organizers and their leading experts.

The workshop was launched in March 2020 through an opening conference that was meant to offer insights on the CLIC project's fundamentals and results, and examples from professionals and experts in the fields of the circular economy, cultural-heritage preservation and its adaptive reuse, building-material recycling and urban-heritage governance. These concepts were introduced broadly from a theoretical viewpoint by reducing the list of practical examples and not influencing and overburdening the participants with the final solutions, thus encouraging freedom in thinking about how to solve perceived spatial issues. Originally, three main intense face-to-face workshops were scheduled, but due to the epidemic situation in Italy, Slovenia and Croatia, and measures taken to contain the COVID-19 virus, a reorganization was required, leading to more frequent, weekly online meetings. For the nature of online meetings, the workshop might not have been as interactive as initially anticipated; therefore, the engagement of the local mentors from the University of Rijeka and DAR - Architects Association of Rijeka was essential for the 
participants' engagement and the discussion coordination, proposal evolution and work development. Due to the workshop's reorganization, the whole area was divided into smaller areas to be easily workable, although participants had to finally keep in mind the Cultural Corridor area's wholeness and integrate their proposals. The participants were arranged into five groups, each with an area and a topic and a mentor in the architectural/planning field, and comentored by experts covering economy, marketing and product design. The five working areas of the workshop were:

- The transverse corridor, crossing the inner-city area and connecting the Benčić Complex with the river and channel area at the Delta, where it overlaps with the Cultural Corridor;

- The whole Rječina and Dead Channel area from Rječina Canyon to the river's mouth in the Delta;

- The Rječina upper-stream area from Školjić to the Rječina Canyon, including adjoining streets on both banks (Ružićeva Street and Vodovodna Street);

- The specific intersection in the inner-city area, aiming to extend the cultural and social attractions from the main city street Korzo; and

- The Rijeka primary waterfront, by the Riva and Riva Bodulli, with the Galeb Ship to be moored at Molo Longo breakwater, connecting Port Baross and the Delta.

The participants working in group 1 (Figure 6) on the Benčić Complex Area revitalisation were asked to address the topic of inner-urban spatial integration of new cultural infrastructure at Benčić Area, the exteriors and the spatial connection between the renovated (Šečerana Palace, Children's House, City Library and Museum of Modern and Contemporary Art) and unused buildings (Teatrino), as well as the transverse connection leading toward the Cultural Corridor Area.

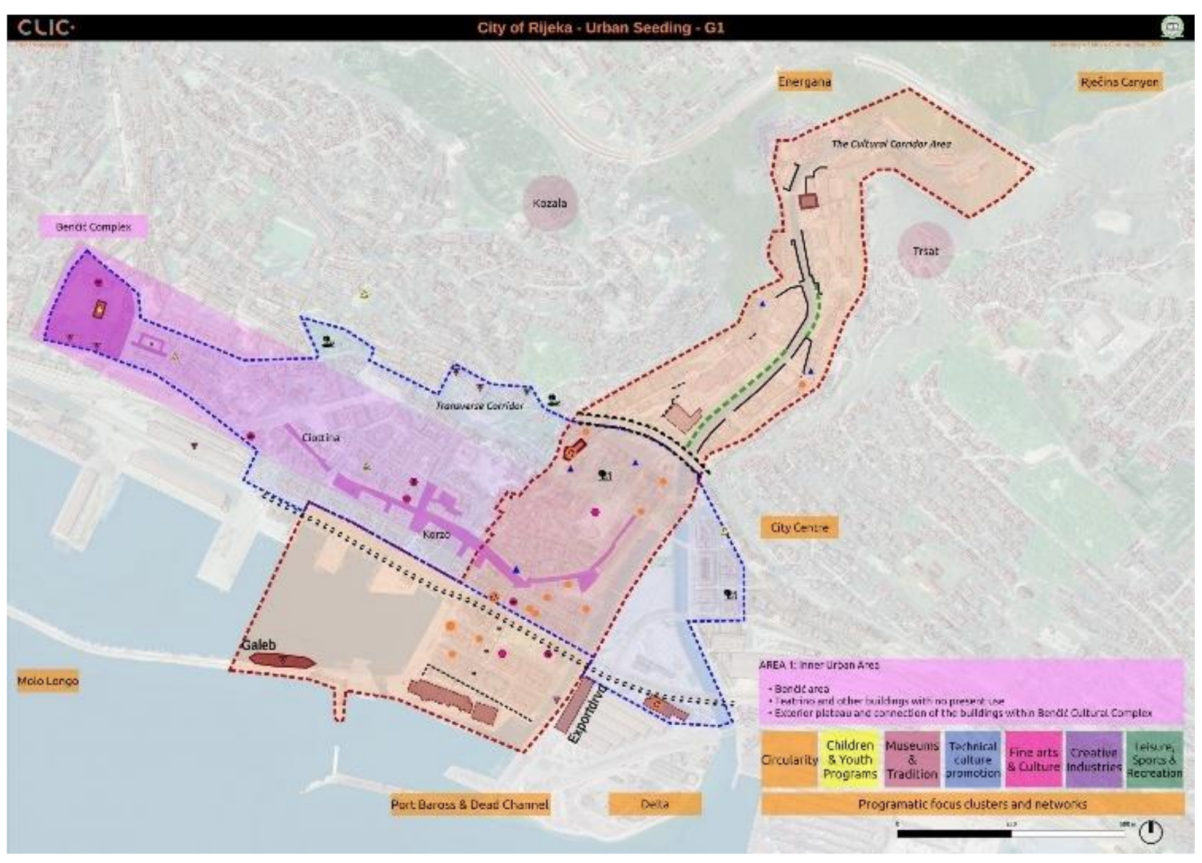

Figure 6. Working area of group 1, connecting Benčić complex through Korzo with the Cultural Corridor. Map credit: Maja Debevec. Cartographic data: City of Rijeka, 2018.

The second and third groups (Figure 7) focused on revitalising the Rječina and Dead Channel waterfronts and their connection to the surrounding urban areas and city center. Specifically, the third group had to concentrate on the urban greenscape, imagining the ways existing and new green interventions in the Cultural Corridor area could enhance the perception of build heritage and historic urban landscapes, and could integrate the latter in terms of accessibility. 


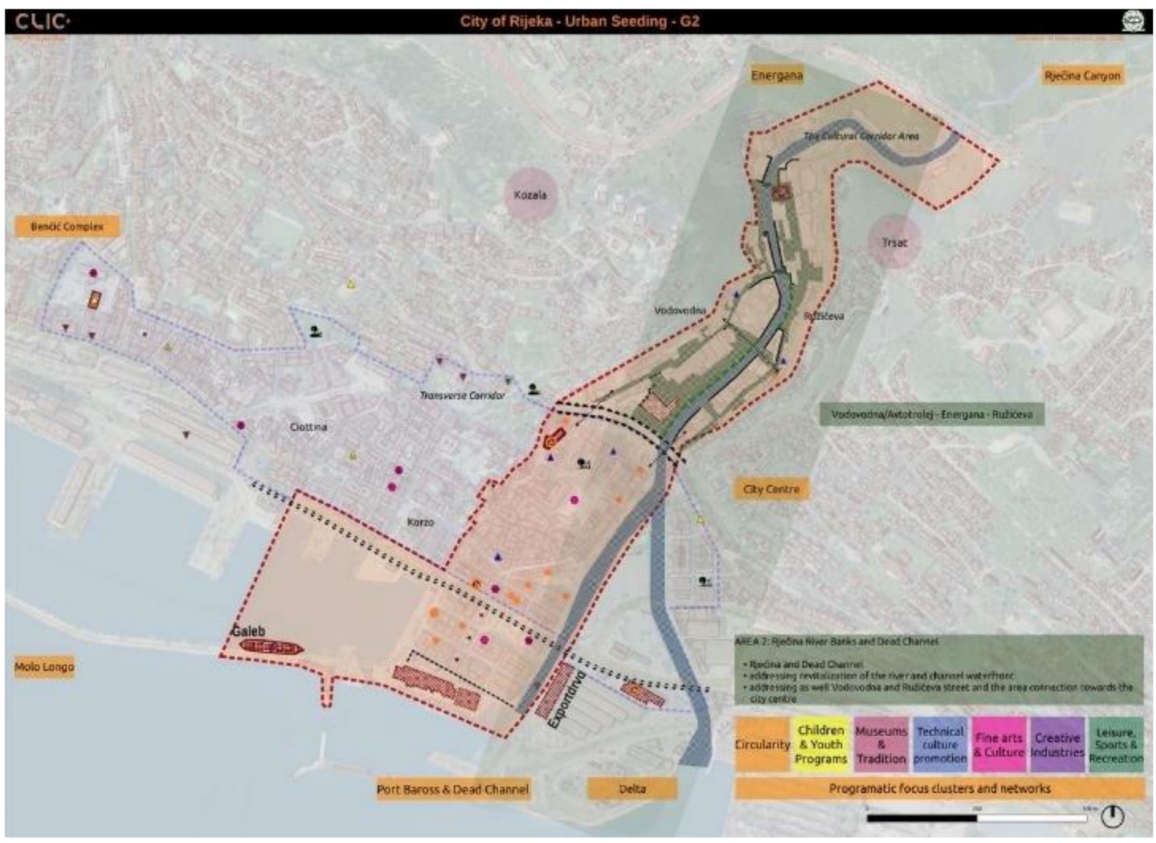

Figure 7. Working area of groups 2 and 3, focusing on Rječina and the urban greenscape. Map credit: Maja Debevec. Cartographic data: City of Rijeka, 2018.

The specificity of the fourth group working on the historic town center's inner urbanscape (Figure 8) addresses the ground floors of vacant business premises and empty spaces in front of them, introducing the potential circular-economy activities envisaging tradition and cultural innovation. The participants also had to address the connection leading toward Korzo, Rijeka's main street.

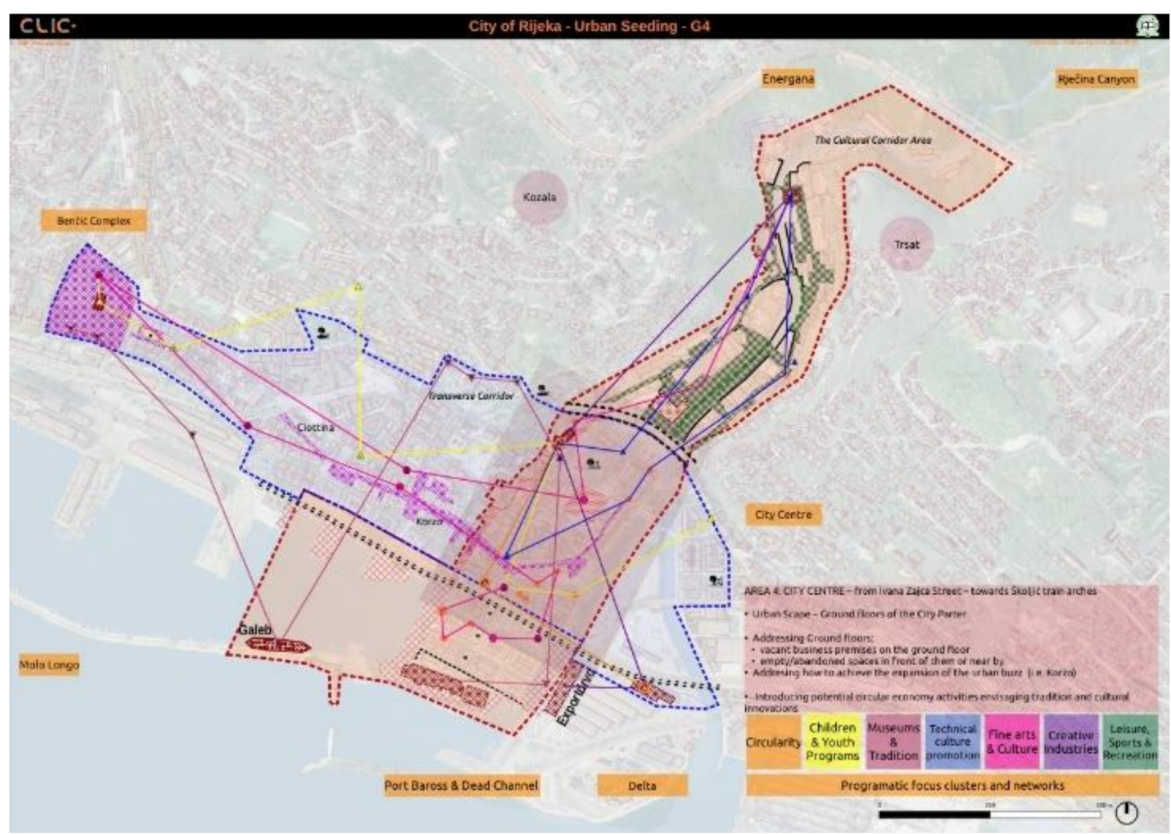

Figure 8. The group 4 planning area, which focused on the inner urbanscape. Map credit: Maja Debevec. Cartographic data: City of Rijeka, 2018.

The topic of Cultural and Social scape was developed by the fifth group (Figure 9), addressing the waterfront connection (Port Baross/Dead Channel) with the city center 
and Delta area through possible new cultural and social innovations acting as urbanregeneration initiators.

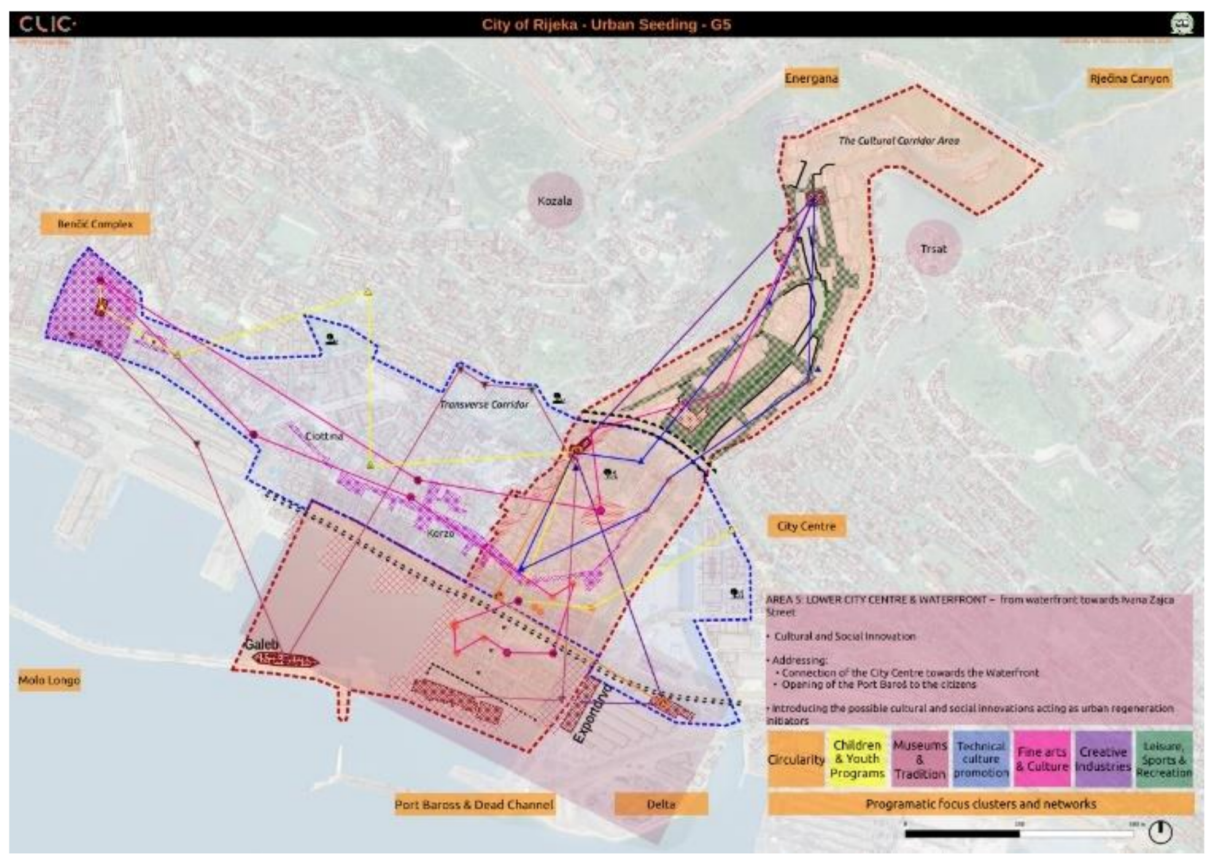

Figure 9. The Sea waterfront, the focus area of group 5. Map credit: Maja Debevec. Cartographic data: City of Rijeka, 2018.

As a first step, the participants were encouraged to familiarize themselves with the area by taking an onsite spatial reading of their selected area, as well as the whole cultural corridor area, following the instructions based on the principles of the Jane's Walk Initiative [87] and followed by in-depth research of the spatial history and its development in order to share it in discussion with other participants in intermediate meetings, transferring knowledge on a peer-to-peer level. In this manner, the tasks were becoming more defined weekly, and the participants presented the developed proposals to everyone, receiving feedback from their peers, mentors and stakeholders.

Even though the groups focused on the specific area within the Cultural Corridor area, each had to consider how their group's concept integrated with the overall corridor area. In the design process, they had to consider various dimensions on several levels:

1. Urban or spatial dimension, by considering urban and public spaces' connectivity, mobility, accessibility, urban services and infrastructure, and bridging the gaps to provide better pedestrian safety and use;

2. Circular dimension concerning cultural heritage on three scales (urban, building and object) by creating local circular loops and local partnerships for raising the additional value of the cultural heritage itself;

3. Cultural and natural heritage (assets) and environmental integration through the adaptive reuse of cultural heritage through awareness-raising and positive environmental impact; and

4. Social, cultural and economic dimensions by empowerment through social activation and sharing economies.

Establishing a clear-thinking pattern incorporating these notions, the groups were asked to plan possible uses to connect to existing services and activities offered in the city of Rijeka and define the possible activities related to the foreseen uses. In the final proposals, the participants overlapped the small actions, connected through the groups' urban visions and complementarily creating a connected system through other groups' proposals to inspire and facilitate Urban Seed replication in the city, its surroundings and elsewhere. 
The prepared proposals were for five identified areas within the Cultural Corridor and its transverse connection toward the new Benčić cultural quarter; therefore, they integrated selection of solutions (Urban Seeds) characterized by those readily implemented in the city, which are low cost, replicable and respect the urban heritage of the city center. The future implementation facilitation could be taken by local civil society organizations and NGOs from their respective fields under the city's coordination.

\section{Results}

The work of the groups produced rich ideas presented in graphic materials and evaluation grids. The latter contributed to the testing, with the University of Portsmouth, of another tool called the Decision Support System-CLIC DSS, also foreseen in CLIC.

- Group 1-Benčić Art Kvart

Some ideas for the Benčić Complex, a sort of museum district [88,89] of the city presently missing an adequate integrated connection to the city center, were designed to operate microinterventions enhancing the cultural experience. In particular, this was done by integrating revitalization of assets excluded by the ongoing municipal revitalization process, such as the Teatrino Building, a former small popular theatre, and the Benčić Complex piazza. The stakeholders to be initially included or fostering implementation were mapped.

For the Teatrino Building, interior and exterior interventions revitalizing the building through do-it-together workshops were imagined. The Teatrino would host a multipurpose space for various creative uses, such as puppet shows, workshops for puppet creation, performances, seminars, etc., together with providing essential utilities and services (sanitary facilities). The facade's exterior interventions focus on the regreening and creation of art murals by respecting the building's material substance and allowing the facade's upgrade and decoration through participatory community workshops.

The public open spaces in the Benčić Complex Area would be repaved reusing the stones removed in the renovations of nearby Šečerana palace and amended with traditional children's games and instruction panels on the game rules (for example, Cip-Cop game). The wooden rest areas and urban furniture would form a central park in the Benčić Complex.

The main direction of revitalization in Benčič was social strengthening through various social activities; promotion of sharing economies (book-sharing, plant/seedling swap/sharing); providing opportunities for raising awareness through workshops on sustainability, food growing/sowing, socialising and reuse/recycle/upcycle (building urban furniture, regreening, planting, coloring, etc.); exchange of goods in the flea market; and studying space for students.

- Group 2-Rječina \& Dead Channel Waterfront: Ružićeva Street, Vodovodna Street

This group focused more on the natural assets of the initial part of the Rječina River, often referring to the historical-cultural and natural assets present there, such as the staircases from the Austro-Hungarian period, connecting the canyon area with the Trsat Castle and Kozala on the hills behind (Figure 10):

The overall idea works on improving accessibility through an upgrade of sports and recreation infrastructure to promote a healthier lifestyle, commencing from similar activities by identified stakeholders in the area.

- This is how one proposal addresses the reuse of natural resources (rock cliffs) and cultural heritage (Hartea Staircases) by developing rock climbing as a local activity present in the area (new climbing school) and thus revitalizing the connection to the Trsat and Kozala through sports. The creation of a cycling path for leisure and recreation by using the rare natural feature of flat terrain in Rijeka by the Rječina River would connect with the city districts at a higher 
elevation using city transportation buses upgraded with bike-racks/carriers (coming to the city with the bike, returning by bus).

The River Waterfront redevelopment would give access to the water by providing new infrastructure and regulation of riverbanks. The terraced river waterfront with a green beach and a new cycling path would provide the diverse possibility of use and a leisure destination in Rijeka's center, offering fun, sports, recreation and reading (small interventions like book-sharing houses).

- The project encompasses preserving the city's cultural heritage and its HUL by creating a river market on the Dead Channel and revitalizing the Školjić city pool. The flea market on boats was modeled based on the channel's history, where in the early 20th century, fishermen were selling fresh fish directly from their boats.

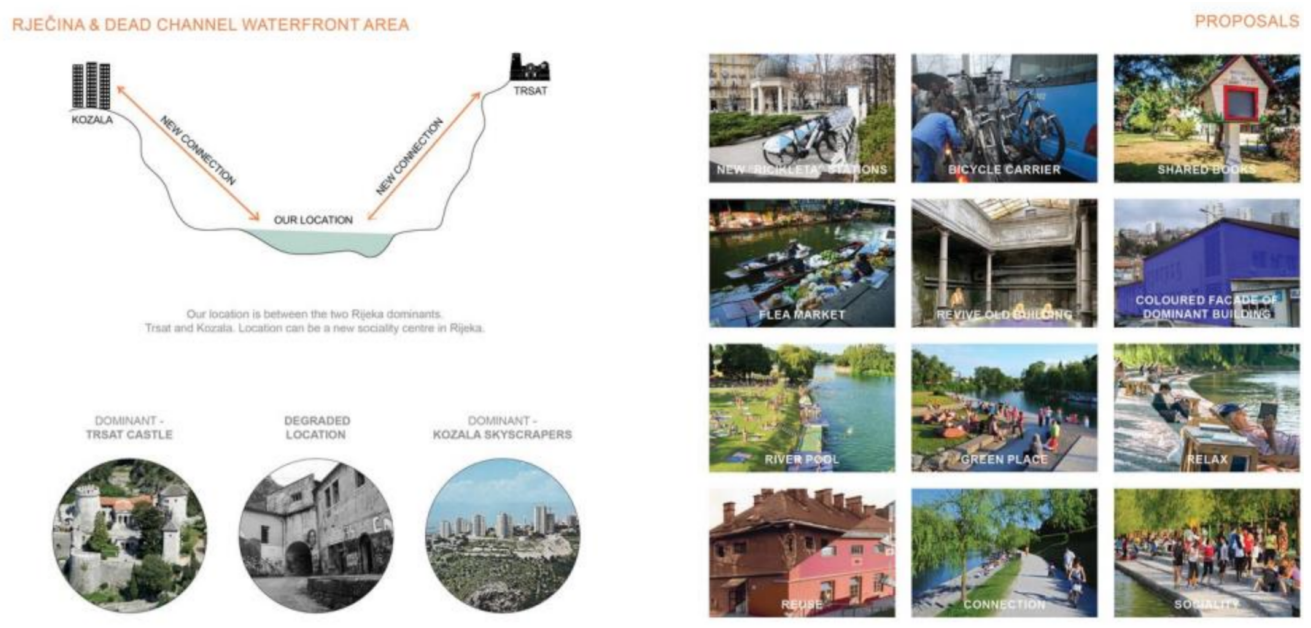

Figure 10. Section of the group 2 presentation for Rječina and the Dead Channel waterfront, proposing urban sports and leisure activities. Presentation credit: Tin Komadina.

The city pool Školjić needs a complete renovation and, in some parts, even reconstruction. The group proposed a colored facade in a bright color, as done for the Museum of Modern and Contemporary Art, to attract broader interest and, consequently, a complete renovation of the pool.

- Group 3: The Green Scape of the Cultural Corridor Area

This group developed areas along the Rječina River, the Dead Channel and the Delta area, presently entirely devoted to parking spaces, by focusing on green areas and abandoned or underused industrial sites. The stakeholders to be initially included in the processes were identified:

- The overall idea is based on the traffic reorganization of the Ružičeva and Vodovodna streets, turning them into a one-way direction, with an entry at Ružičeva Street and exit at Vodovodna Street. The project tries to solve different levels of the area's traffic burden. The traffic reorganization would allow stronger pedestrianization of the area by moving the cars occupying the area into a new green parking garage in the Školjić Autorolej area. Additionally, the Autotrolej area, being emptied of the public bus garage, would be redeveloped as a new park, continuing the current Tree Alley by the Rječina. The pedestrianized area would therefore connect to the city center's pedestrianised areas with much less effort.

- The new pedestrianized areas would allow the introduction of simple and common small-scale solutions that also offer a new interpretation of the cultural history of Rijeka. A history window made of recycled glass/plexiglass, displaying the historic scenery outlined by the current view, would show the landscape of Rijeka in the past. By implementing QR codes links, citizens/visitors could 
obtain more information about the areas, thus raising heritage awareness. The simple regreening solutions were introduced along the new pedestrianized area, reusing the light poles and other public infrastructure fixtures.

- Focusing on the adaptive reuse of the whole Hartera area, the group proposed creating urban gardens on the flat roofs of the Hartera facilities, providing the vegetables for the restaurant and culinary workshops in the Energana power plant, where craft beer would also be produced. In the aqueduct area of Hartera, the group proposed the galleries and exhibition spaces for Rijeka's young artists and the art school's bazaar, accompanied by recurring social and cultural activities, creating murals and 3D graffiti, and promoting natural and cultural heritage under the hashtag \#RIJEKATEDRŽI.

- Connecting to group 4 proposals for repair shops and reuse activities in Vitezovićeva Street, group 3 proposed the organization of exchange/swap/share events of various items (books, clothes, furniture, etc.) in the new pedestrianized squares and streets in the city center (Kobler Square, St. Barbara Square, Paulines Square, Klobučarić Square, Jelačić Square, Theatre Square), assisted by reuse/repair/upgrade services (group 4) of the swapped materials at the event.

- Group 4: The City Center

Group 4 worked on the historic center, trying to integrate the presently highly used cultural assets with the less valued ones, mainly located close to the river and the canal. References to the archaeological remains and the narrow medieval streets were made, with interesting connections to circular-economy practices in buildings' adaptive reuse.

In Urban Vision, they focused on reviving abandoned parts of the city by introducing circular-economy practices and preserving cultural heritage. This is how, in the street of Pavel Ritter Vitezović, they proposed to reuse the abandoned ground-floor business premises to be repurposed for second-hand shops, workshops for furniture repairs and production of recycled-glass objects. Additionally, the newly introduced Nature-Based Solution (NBS) Cloud above the ground-floor level, providing shade and additional greenery, heavily lacking in the city center, would enclose the street as a whole.

- In the Ivan Klobučarić Square, the group redesigned the encaged children's play area into a friendlier and more welcoming area. Extending the RiCikleta network by providing a new station in the square is needed for urban connectivity within the city center, adjoining the existing underground garage. Moreover, addressing the HUL principles, they proposed reusing the abandoned building site's concrete foundation slabs as bases for the exhibition showrooms made of recycled glass and exhibiting the city of Rijeka's history. Nearby, the historic city walls, currently stored behind an advertisement board, would be reused, partly enclosing the rest area with the city model and providing shade. The possibility of conservation and exhibition of the ancient Tarsatica mosaics in front of the former Christian Basilica nearby was considered.

- Contributing to the circular-economy implementation, the group developed the Vitezović street's programmatic focus, creating a local loop of reuse/recycle/ upcycle/restore/resell activities, thus enhancing the socioeconomic situation of the area. The growing demand for refurbishing old apartments with rustic or original furniture and decoration opens an opportunity to develop the restoration of old furniture. Allowing citizens to restore, sell or buy furniture or other products in one place, instead of throwing them away, references the City Service Riperaj - the repair cafe. The group considered that repurposing materials, such as old clothes, textiles and the waste glass, would reduce the 
environmental impact; for example, each metric ton of reused glass in the production of new glass emits $315 \mathrm{~kg}$ less of carbon dioxide emissions.

- Group 5: The Lower Waterfront

Group 5 focused on the lower waterfront, highlighting the tangible and intangible potentials of the area. Among the proposals was the connection with the nearby historical market for food-waste avoidance, generating a virtuous circle with tangible and intangible sources. The overall idea works to raise awareness for cultural heritage and bridge the secluded area gap by attracting people to the area, enabling access and repurposing the area through preservation and area cocreation. The potential stakeholders to be included in the process were also identified (Figure 11):
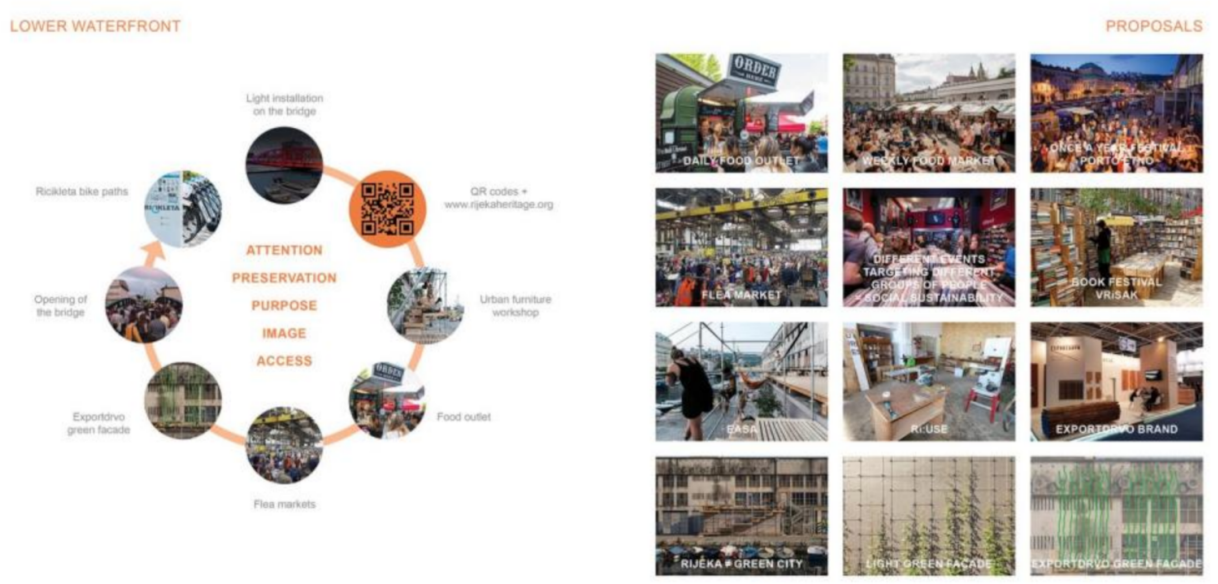

Figure 11. Section of the group 5 presentation for the lower waterfront's circular logic of the proposed actions. Presentation credit: Mia Bećirević.

- Creating a light installation on the Heritage Movable Bridge and its subsequent opening would make the area more accessible and reorganize the movement flow. The idea was transferred from the nearby Port Cranes installation and can connect further industrial-heritage city landmarks, such as the Energana Chimney. Additionally, QR codes would be installed on the cultural-heritage assets to achieve synergy with the University of Rijeka's rijekaheritage.org project.

- The Exportdrvo building's adaptive reuse was imagined as a multipurpose event venue, providing events focusing on social sustainability, alternating weekly/monthly, and gradually taking over the space. Prototyping and creating urban furniture and providing workshops would link the new and original use of the building (export timber warehouse). The exterior of Exportdrvo would be enhanced by the introduction of the NBS solution, bringing the greenery into the built lower city center, using steel wire supports for climbing plants following the facade openings pattern.

- The Food Outlet/Street Food Market would prepare meals based on daily market surplus, offering healthy food at affordable prices in front of the Exportdrvo building. In reference to the existing yearly event of the PortoEtno Festival, the outlets would be recurring on daily and weekly bases, encompassed by the yearly event.

The work of the groups did not stop at these findings. In a final session, groups were asked to integrate their proposals and find possible integration means, jointly evaluating the most replicable solutions and those that may have impacted the creation of the Cultural Corridor more. More details are to be published in a small booklet. 


\section{Discussion}

This paper has presented two connected experimental ideas carried out in Rijeka using the CLIC project's framework. Two experiences aimed at generating a conceptual approach by merging the historic urban landscape with the circular economy, passing through cultural-heritage renovation. The implementation highlights some gaps.

First, there is a gap in knowledge on several important issues regarding the conservation doctrine and its practice. The response to this may come from other possible tools to be put in place that are still part of local authorities' daily practice in many but different contexts, such as manuals for conservation and maintenance practices, booklets on the circular economy, solutions for urban-ecosystem regeneration, etc. In this respect, steps have been seriously taken, as we have seen in the administrative reports and general literature mentioned in the paper, but the field's responses are still behind.

Second, the circular economy's core contrasts with the traditional linear economy adopted daily by most people everywhere, Rijeka included, a fact that requires a behavioral reference. We have witnessed, though, that younger generations are accustomed to the new trends and are willing to contribute to a green change by engaging in sustainable behaviors.

\subsection{About the Corridor}

With these small gaps in mind, the experience in Rijeka at large seems promising as an occasion to test the theory of Common Pool Resource Management, to condense the motivations of the Council of Europe's Convention on the Landscape (2000), the Values of Heritage for Society (2005) and the Recommendation on the Historic Urban Landscape (UNESCO 2011):

- The Common Pool Resource, because the corridor is establishing within clear boundaries-in the case of Rijeka, offered by the geomorphology of the city and the perception of the actors interviewed, as well as by linking the three CLIC assets, Energana, Rihub and Galeb — an enlarged community-based and managed resource, in which the leading conditions are the absence of excludability but an intense (potential) rivalry. Within the corridor, the conditions are set, namely the respect of the circular economy's principles, the valorization of the city's cultural and natural heritage, tangible and intangible, and essential commitment. To achieve the proper corridor function, the integration of uses, multifunctionality and proximity are important for the proper attractiveness, cooperation and competitiveness that characterize the cultural districts $[88,89]$. To let the corridor work in its cultural mission, accessibility should be adequately addressed in a sustainable, human-centered, safe and healthy way.

- The Cultural Corridor was designed to be codesigned. The CoE 2000 Convention's main contribution was to consider landscape as "perceived by people": this has been feeding the international debate for two decades, asking for explanations and specifications. The Cultural Corridor in Rijeka has demonstrated that space can become a place again if the contribution comes from users' experience, aware of history and capable of reimagining future use.

- The aesthetic or heritage community is essential for the corridor, and this is why this notion grasped and gave to the CoE Faro Convention (2005). The corridor's community is not simply "local", but is an extended one made of those who care, and is open to others that do care about culture, cultural heritage and the circular economy. However, care is not enough, because there is a lot of competence to be guaranteed in the process, and such competence should be built up through experts, policymakers, enthusiasts and specialists, as local professionals, craftsmen and artisans. As per the common pool resource concept, actors are essential to contribute to and monitor the progress of the place.

- The Cultural Corridor in Rijeka is a sort of stratification of the city's history, displaying many of its layers through tangible and intangible assets. It contains the rivers and the channels that gave birth to the city; the historic castle path; the industrial buildings and infrastructure; the medieval, Austro-Hungarian, socialist and modern architecture; 
and the aggregation and production places of the city through centuries, although not all are clearly shown, but are in a reasonable combination. The corridor also includes the sea, which has been for too long left aside in the city. All these assets require regeneration; some need adaptive reuse, some need maintenance, and others simply need attention and promotion; the Heritage Innovative Partnership process has highlighted participants' interest to consider this as the proper area to relaunch the city. In this respect, it was the predecessor to the implementation of the HUL approach in the city.

Within the Cultural Corridor concept, we should not forget two important contributions; namely, the European Capital of Culture 2020 (ECoC 2020) and the European Green Deal. If the former has a direct, immediate contribution in and to the area, being the premises of ECoC 2020 in the Delta and being the most of foreseen activities performed in the city center, the latter will have a possible crucial positive impact on the success of the corridor. The Green Deal will take important innovations in the city, either through local and national government rulings or facilitation by researchers' and professionals' activities. For the conformation of the area and its potentials for citizen health, numerous improvements are expected, from biodiversity restoration through greening, afforestation and water cleaning, to energy efficiency and climate-change fight through building retrofitting, sustainable-infrastructure introduction and slow nonpolluting mobility measures. Culture is always associated with health and nature, both because it contributes to and benefits from it; this is likely happening in historic urban landscapes.

\subsection{About Urban Seeding}

Urban Seeding also gives an added value to the international debate, although it cannot stand alone in the implementation of the Cultural Corridor, and cannot be based on general assumptions for the traditional living labs or communities of practice. In Urban Seeding, the following factors were considered necessary:

- The participants should be highly motivated and skilled. The initial intention was to have, in fact, young professionals at the early stage of their careers or students in their final study year to conduct intense research and participate in the aspects of the circular economy as applied to culture and cultural space. The reason behind this, which was not immediately grasped by participants, was to open an individual and group investigation about the potential business and job opportunities behind the work, with the ambition to possibly promote new circular-economy entrepreneurs. The working groups' composition had to be multidisciplinary and the groups not too numerous, permitting dialogue, self-production and equal expression to make proposals balanced in terms of economic feasibility and impact, cultural preservation or promotion, and environmental appropriateness and social benefit.

- Although focusing on microactions, Urban Seeding should develop planning ideas at different scales of intervention. This initial idea was fundamental to differentiate from many of the existing practices in space-making. Participants, although divided into groups with different areas and different topics, had to see their commitment at a different scale because one of the Cultural Corridor's key factors is the integration and complementarity of projects to avoid unbalanced economies in its extension. Additionally, the seeds have to be replicable, and this condition can be achieved if there is awareness of other areas' constraints and potentials.

- Failing should be a possibility. This is the natural condition of the seeds. Even though they were low-cost and easily applicable, some of the proposals could not work in some areas, but could be extremely successful in some others. The factors of success can be partly predicted, and depend on different internal and external conditions.

- Relevant stakeholders must be partly committed to contributing to the implementation of ideas. This aspect could only be partially explored in the process due to the COVID-19 pandemic, but the relevant stakeholders' interest in contributing may or may not allow the seeds to happen. Approval and contributions, which include 
suggestions and accompaniment, should be in line with local policies, be fundable, and be "political" as well.

Many other tools were imagined for the Cultural Corridor and Rijeka. They included dissemination manuals, educational platforms, legislative measures and financial schemes, which have to be aligned with a clear strategy for a sustainable circular cultural city, as explained in the project documents.

From the experience of Rijeka in CLIC, the future research scenario in this field comprehends different commitments:

- Continuing the research for education in the project fields, namely the circular economy, cultural-heritage preservation and historic urban landscape management. Still, in Europe, there is a different understanding of the fundamentals in all disciplines, and this may depend on many factors that are not merely rooted in the economic scenarios;

- Continuing the research on "participatory practices". If there is an undoubted contribution by society's involvement at large in the regeneration process, the success is not yet fully guaranteed. In the Rijeka case, in which the participatory workshops were limited to professionals and students at their late academic stages, the pandemic opened important questions about the feasibility of participatory processes when participation is not possible. Design and planning still very much depend on experts' knowledge and competence, and the research should favor the understanding of this.

- Research tends to forget that urban policies need different scales, and all must coexist. Regenerating a city cannot be based merely on local spared actions, but forms of governance also are needed to guarantee the appropriate creativity regarding an "urban landscape". To date, there is a risk to level the specific knowledge in different fields of expertise to accommodate generalized and globalized trends. This can be clearly seen when talking about cultural-heritage preservation, reuse, adaptation, maintenance, etc.

\section{Conclusions}

The city of Rijeka is an extremely dynamic urban agglomerate. It is cleverly adapting from a former socialist economy to a liberal one, relying on its traditions and cultural and human capital. Different from that of many other European and global cities, this transition is predominantly based on citizens' well-being instead of visitors and tourists' satisfaction, and depends much on local young generations' education. This aptitude of the city represented fertile ground for the CLIC project's attempts to merge the circular economy with cultural heritage sustainable reuse, in light of the city's exceptional potentials in terms of the historic urban landscape and real estate redevelopment opportunities. The challenge was to combine the circular movements of nature and cultural traditions with the linear evolution of development projects.

Counting on a solid awareness of local actors and citizens regarding the past, present and future of the city, CLIC's performed activities naturally produced a development model that was inspired by multiple disciplines and different experiences, but could theoretically work in the city. The efforts for a regeneration of historic urban assets mimicking other international experiences but avoiding the typical jeopardized, monument-based processes, should have passed through an integrated approach that included nature and sustainability since the very beginning. The constraints, however, imposed by the project itself and by the participants, were to pay attention to nature, health and inclusion. These inputs highlighted a circular spatial corridor moving from the waterfront to the city river's inner canyon and back, where experimentations of the circular economy and cultural heritage adaptive reuse could be made and replicated. Such a corridor was renamed the Rijeka Cultural Corridor, and for its characteristics, it has been assimilated into a common pool resource as intended by Ostrom in the common-goods theory. Such a corridor has become a model for implementing theories on the circular economy in sustainable historic urban landscapes, stimulating debates on the tools to be put in place, sometimes invented, to make it feasible. 
Among the possible tools to achieve the Cultural Corridor, the partnership has elaborated Urban Seeding, a workshop methodology based on situated learning made of a set of proposals for small local urban interventions or actions, both temporary and permanent, providing the community's activation through a diversity of use, programs, actions and events that are specifically meant to enable attention. If indeed the design and quality of space can be easily perceived and performed by specialists, then nonspecialists, and common citizens may need examples to become familiar with the aesthetic dimension of heritage. Based on the ideas of continuity and proximity, temporary initiatives may gradually become recurrent or permanent installations, actions or events in the urban and green areas and vacant premises of the city parterre. The objective became the sprouting these microinterventions from the local needs. Though the Urban Seeds address the spatial context and its heritage through the circular economy's principles, the generalized idea is to be inspirational and replicable elsewhere, while focusing on the landscape (urbanscape) approach.

The initiative, regrettably impacted by the pandemic, demonstrated a good methodology to propose and promote low-cost and replicable ideas to create a new usable space capable of attracting users in a sustainable and creative environment. Moreover, although not fully implemented, the experiment showed a good balance in rapidly stimulating sustainable solutions with careful respect to design, considered in the process as a fundamental factor for the enhancement of the historic urban landscape.

Author Contributions: Conceptualization, M.A., S.D. and M.D.; methodology, M.A., S.D. and M.D.; validation, M.A., S.D. and M.D.; formal analysis, M.A., S.D. and M.D.; investigation, M.A., S.D. and M.D.; resources, M.A., S.D. and M.D.; data curation, M.A., S.D. and M.D.; writing-original draft preparation, M.A., S.D. and M.D.; writing-review and editing, M.A., S.D. and M.D.; visualization, M.D.; supervision, S.D.; project administration, M.A.; funding acquisition, M.A. and S.D. All authors have read and agreed to the published version of the manuscript.

Funding: This research was funded under the framework of the Horizon 2020 research project "CLIC: Circular models Leveraging Investments in Cultural heritage adaptive reuse". The CLIC project received funding from the European Union's Horizon 2020 research and innovation program under Grant Agreement No. 776758.

Institutional Review Board Statement: The research did not involve studies on humans or animals.

Informed Consent Statement: The research did not involve studies on humans or animals.

Data Availability Statement: The City of Rijeka provided public data used in the study. Research results of CLIC Pilot in Rijeka, taken by ICHEC Brussels, were used as a reference for further development of CLIC Pilot in Rijeka. The results of participants proposals are available upon request. For the presentation sections published in this paper, permission to publish has been obtained.

Acknowledgments: The authors would like to acknowledge the contributions of the City of Rijeka, the stakeholders involved in the Heritage Innovation Partnership Process; the University of RijekaFaculty of Civil Engineering, Faculty of Economics, Academy of Applied Arts and their mentors participating in the Urban Seeding Workshop: Marko Franković, Iva Mrak, Ana Brusić Batistić, Ivana First Koman and Branimir Paškvan; as well as the participants of the Urban Seeding Workshop, Group 1 (Ana Berljafa, Ariana Domijan, Dora Gabrijel, Michel Jakić, Nikola Roginić), Group 2 (Tin Komadina, Anamarija Krajinović, Kristina Kustić, Katarina Prpić, Carla Olujić), Group 3 (Marko Mrvoš, Filip Sambolek, Katarina Sinković, Ines Šoić, Martina Turković), Group 4 (Marijana Bogdanović, Sanel Demark, Lana Grgurić, Ivan Petrašević, Toni Pogačić) and Group 5 (Mia Bećirević, Josip Ilić, Ana Krunić, Andrej Šaina, Amalija Zubić). The authors also gratefully thank Gillian Foster, Cristina Garzillo, Simona Panaro, Matthias Ripp, Jukka Jokilehto, Xavier Greffe, Valentina Gamba, Suzana Belošević Romac, Tajana Jukić-Neznanović, Verena Lelas Turak and Sonja Lukin for their insights, contributions and fruitful discussions.

Conflicts of Interest: The authors declare no conflict of interest. The funders had no role in the design of the study; in the collection, analyses, or interpretation of data; in the writing of the manuscript; or in the decision to publish results. 


\section{References}

1. Cervellati, P. La Nuova Cultura Delle Citta': La Salvaguardia Dei Centri Storici, La Riappropriazione Sociale Degli Organismi Urbani e l'analisi Dello Sviluppo Territoriale Nell'esperienza Di Bologna; Edizioni scientifiche e tecniche; Mondadori: Milan, Italy, 1977.

2. Masboungi, A.; Bourdin, A. Un Urbanisme des Modes de Vie; Le Moniteur: Paris, France, 2004; ISBN 978-2-281-19232-2.

3. Dobbs, R.; Remes, J.; Manyika, J.; Roxbourg, C.; Smit, S.; Schaer, F. McKinsey Global InstituteUrban World: Cities and the Rise of the Consuming Class; McKinsey Global Institute: New York, NY, USA, 2012.

4. Moretti, E. Human capital externalities in cities. In Handbook of Regional and Urban Economics; Henderson, J.V., Thisse, J.F., Eds.; Elsevier: Amsterdam, The Netherlands, 2004; Volume 4, pp. 2243-2291.

5. Florida, R.L. The Rise of the Creative Class: And How It's Transforming Work, Leisure, Community and Everyday Life; Basic Books: New York, NY, USA, 2004; ISBN 978-0-465-02477-3.

6. De Cesari, C.; Dimova, R. Heritage, Gentrification, Participation: Remaking Urban Landscapes in the Name of Culture and Historic Preservation. Int. J. Herit. Stud. 2019, 25, 863-869. [CrossRef]

7. Barile, S.; Saviano, M. From the Management of Cultural Heritage to the Governance of the Cultural Heritage System. In Cultural Heritage and Value Creation; Golinelli, G.M., Ed.; Springer: Cham, Switzerlands, 2015; ISBN 978-3-319-08526-5.

8. Heidenreich, M.; Plaza, B. Renewal through Culture? The Role of Museums in the Renewal of Industrial Regions in Europe. Eur. Plan. Stud. 2015, 23, 1441-1455. [CrossRef]

9. Van den Berg, L.; Van der Meer, J.; Carvalho, L. Cities as Engines of Sustainable Competitiveness: European Urban Policy in Practice; Routledge: London, UK, 2016; ISBN 978-1-138-27983-4.

10. Florida, R.L. Cities and the Creative Class; Routledge: New York, NY, USA, 2005; ISBN 978-0-415-94886-9.

11. UNESCO. Convention for the Safeguarding of the Intangible Cultural Heritage-UNESCO Digital Library. Available online: https://unesdoc.unesco.org/ark:/48223/pf0000132540 (accessed on 20 February 2021).

12. García-Hernández, M.; de la Calle-Vaquero, M.; Yubero, C. Cultural Heritage and Urban Tourism: Historic City Centres under Pressure. Sustainability 2017, 9, 1346. [CrossRef]

13. Ashworth, G.J.; Tunbridge, J.E. The Tourist-Historic City: Retrospect and Prospect of Managing the Heritage City. Advances in Tourism Research Series, 1st ed.; Pergamon: Amsterdam, The Neteherlands; New York, NY, USA, 2000; ISBN 978-0-08-043675-3.

14. Landry, C. The Creative City: A Toolkit for Urban Innovators; Earthscan Publications: London, UK, 2000; ISBN 978-1-85383-613-8.

15. Landry, C. The Art of City-Making; Earthscan: Sterling, VA, USA, 2006; ISBN 978-1-84407-245-3.

16. Zukin, S. Gentrification: Culture and Capital in the Urban Core. Annu. Rev. Sociol. 1987, 13, 129-147. [CrossRef]

17. Zukin, S. Naked City: The Death and Life of Authentic Urban Places, softcover ed.; Oxford University Press: Oxford, UK, 2011; ISBN 978-0-19-979446-1.

18. Fusco Girard, L. The Regenerative City and Wealth Creation/Conservation: The Role of Urban Planning. IJGENVI 2014, 13, 118-140. [CrossRef]

19. OECD. OECD Regions and Cities at a Glance 2020; OECD: Paris, France, 2020.

20. Dobričić, S.; Acri, M. Creative Cities: Which (Historic) Urban Landscape; Architettura; Mimesis: Milano, Italy, 2018; ISBN 978-88-5754795-4.

21. International Council on Monuments and Sites (ICOMOS). European Charter of the Architectural Heritage; Council of Europe: Amsterdam, The Netherlands, 1975.

22. Rodwell, D. Urban Conservation in the 1960s and 1970s: A European Overview. Archit. Herit. 2010, 21, 1-18. [CrossRef]

23. Whitehand, J.W.R.; Conzen, M.R.G. The Urban Landscape: Historical Development and Management; Special publication/Institute of British Geographers; Academic Press: London, UK; New York, NY, USA, 1981; ISBN 978-0-12-747020-7.

24. UNESCO. Recommendatino Concerning the Safeguarding and Contemporary Role of Historic Areas. 1976. Available online: http:/ / portal.unesco.org/en/ev.php-URL_ID=13133\&URL_DO=DO_TOPIC\&URL_SECTION=201.html (accessed on 1 February 2021).

25. Howard, P.; Thompson, I.; Waterton, E.; Atha, M. Introduction. In The Routledge Companion to Landscape Studies; Routledge: Abingdon, UK, 2013; ISBN 978-0-203-09692-5.

26. Tuan, Y.-F. Space and Place: The Perspective of Experience; University of Minnesota Press: Minneapolis, MN, USA, 2011; ISBN 978-0-8166-3877-2.

27. Relph, E. Place and Placelessness; Research in planning and design; Pion Limited: London, UK, 1986; ISBN 978-0-85086-111-2.

28. Cresswell, T. Place: A Short Introduction; Short introductions to geography; Blackwell Pub: Malden, MA, USA, 2004; ISBN 978-1-4051-0671-9.

29. Lefebvre, H. La production de l'espace. In In L'Homme et la Société-Sociologie de la Connaissance Marxisme et Anthropolgie; 1974; Volume 31-32, pp. 15-32. [CrossRef]

30. UNESCO. Vienna Memorandum on "World Heritage and Contemporary Architecture-Managing the Historic Urban Landscape" and Decision 29 COM 5D. Available online: https:/ / whc.unesco.org/en/documents/5965/ (accessed on 13 March 2021).

31. Ashworth, G.J.; Tunbridge, J.E. The Tourist-Historic City. Routledge: London, UK, 2000; ISBN 978-1-136-35580-6.

32. UNESCO. Recommendation on the Historic Urban Landscape. 2011. Available online: http://portal.unesco.org/en/ev.phpURL_ID=48857\%26URL_DO=DO_TOPIC\%26URL_SECTION=201.html (accessed on 1 February 2021).

33. Bandarin, F.; van Oers, R. The Historic Urban Landscape: Managing Heritage in an Urban Century; Wiley Blackwell: Chichester, UK; Hoboken, NJ, USA, 2012; ISBN 978-0-470-65574-0. 
34. Pereira Roders, A.; Bandarin, F. Reshaping Urban Conservation: The Historic Urban Landscape Approach in Action. Creativity, Heritage and the City, 1st ed.; Springer: Singapore, 2019; ISBN 978-981-10-8887-2.

35. Bandarin, F.; van Oers, R. Reconnecting the City: The Historic Urban Landscape Approach and the Future of Urban Heritage; John Wiley \& Sons Inc.: Chichester, West Sussex, UK, 2015; ISBN 978-1-118-38398-8.

36. Ripp, M.; Rodwell, D. The Governance of Urban Heritage. Hist. Environ. 2016, 7, 81-108. [CrossRef]

37. Jokilehto, J. Considerations on Authenticity and Integrity in World Heritage Context. City Time 2006, 2, 16.

38. Stanley-Price, N.; King, J. Conserving the Authentic: Essays in Honour of Jukka Jokilehto; ICCROM conservation studies; ICCROM: Rome, Itlay, 2009; ISBN 978-92-9077-220-0.

39. UNESCO. The Operational Guidelines for the Implementation of the World Heritage Convention. Available online: https: //whc.unesco.org/en/guidelines/ (accessed on 14 March 2021).

40. Jokilehto, J. Questions of Authenticity. Conversaciones...con Herb Stovel 2019, 1, 18.

41. Boström, M.; Davidson, D.J. Environment and Society; Springer: Cham, Switzerlands, 2018; ISBN 978-3-319-76414-6.

42. Gracia Aldaz, J.M.; Zhang, H.; Bokova, I. Unesco Culture: Urban Future: Global Report on Culture for Sustainable Urban Development; UNESCO: Paris, France, 2016; ISBN 978-92-3-100170-3.

43. Fusco Girard, L. The City and the Territory System: Towards The "New Humanism" Paradigm. Agric. Agric. Sci. Procedia 2016, 8, 542-551. [CrossRef]

44. European Commission. Towards a Circular Economy: A Zero Waste Programme for Europe; European Commission: Brussels, Belgium, 2014.

45. European Commission. Closing the Loop: An Eu Action Plan for the Circular Economy; European Commission: Brussels, Belgium, 2015.

46. Gravagnuolo, A.; Angrisano, M.; Fusco Girard, L. Circular Economy Strategies in Eight Historic Port Cities: Criteria and Indicators towards a Circular City Assessment Framework. Sustainability 2019, 11, 3512. [CrossRef]

47. ARUP. ARUP The Circular Economy in the Built Environment; ARUP: London, UK, 2016.

48. Boyd, R.; Acharya, D.; Finch, O. From Principles to Practice: First Steps Towards a Circular Built Environment; ARUP-Elle MCarthur Foundaitno: London, UK, 2018.

49. Wolman, A. The Metabolism of Cities. Sci. Am. 1965, 213, 178-190. [CrossRef]

50. Thomson, G.; Newman, P. Urban Fabrics and Urban Metabolism-From Sustainable to Regenerative Cities. Resour. Conserv. Recycl. 2018, 132, 218-229. [CrossRef]

51. Girard, L.F. The Circular Economy in Transforming a Died Heritage Site into a Living Ecosystem, to Be Managed as a Complex Adaptive Organism. AESTIMUM 2020, 145-180. [CrossRef]

52. Gravagnuolo, A.; Saleh, R.; Ost, C.; Fusco Girard, L. Towards an Evaluation Framework to Assess Cultural Heritage Adaptive Reuse Impacts in the Perspective of the Circular Economy. Urban. Inf. 2018, 28-31. [CrossRef]

53. Fusco Girard, L. Implementing the Circular Economy: The Role of Cultural Heritage as the Entry Point. Which Evaluation Approaches? Bull. Calza Bini Cent. 2019, 245-277. [CrossRef]

54. Maturana, H.R.; Varela, F.J. Autopoiesi e Cognizione: La Realizzazione del Vivente; Marsilio: Venezia, Italy, 2012; ISBN 978-88-3174778-3.

55. Acri, M.; Dobričić, S.; Jokilehto, J. The Circular Economy in Adaptive Reuse: Respecting Authenticity and Integrity. In Proceedings of the "Scienza e Beni Culturali 2019-Il patrimonio culturale in mutamento le sfide dell'uso", Arcadia Ricerche, BressanoneVenice, Venice, Italy, 1-5 July 2019 ; ISBN 978-88-95409-23-8.

56. Dobričić, S.; Jokilehto, J.; Acri, M. The Circular Character of Building Tradition: Which Challenges for the HUL Approach. In Proceedings of the STS Conference Graz 2019—Critical Issues in Science, Technology and Society Studies, 6-7 May 2019, TU Graz, Graz, Austria, 2019.[CrossRef]

57. Foster, G. Planning the Circular City: Focus on Buildings' Environmental Impact. Bull. Calza Bini Cent. 2019, 19, 117-123. [CrossRef]

58. Foster, G.; Saleh, R. The Adaptive Reuse of Cultural Heritage in European Circular City Plans: A Systematic Review. Sustainability 2021, 13, 2889. [CrossRef]

59. Pages Sanchez, J.M.; Schubert, D. Developing Sustainable Port-City Relationships in Europe: An Institutionalist Analysis of Waterfront Projects Governance in Lisbon. Doctoral Dissertation, HafenCity Universität Hamburg, Hamburg, Germany, 2019.

60. Stelli, G. Storia di Fiume: Dalle Origini ai Giorni Nostri; Biblioteca dell'Immagine: Pordenone, Italy, 2017; ISBN 978-88-6391-242-5.

61. Gray, E. Nineteenth-Century Torpedoes and Their Inventors; Naval Institute Press: Annapolis, MD, USA, 2004; ISBN 978-1-59114-341-3.

62. De Vergottini, G. La Costituzione Secondo D'Annunzio; Contemporanea; Luni Editrice: Milano, Italy, 2020; ISBN 978-88-7984-658-5.

63. Franzinelli, M.; Cavassini, P. Fiume: L'ultima Impresa Di D'Annunzio, 1st ed.; Le scie; Mondadori: Milano, Italy, 2009; ISBN 978-88-04-59474-1.

64. Ledeen, M.A. The First Duce: D'Annunzio at Fiume; Johns Hopkins University Press: Baltimore, MD, USA, 1977; ISBN 978-0-80181860-8.

65. Republic of Croatia. Croatian Statistical Reports. Popis Stanovništva, Kućanstava i Stanova 2011. In Stanovništvo Prema Državljanstvu,Narodnosti, Vjeri i Materinskom Jeziku (Census of Population, Households and Dwellings 2011, Population by Citizenship, Ethnicity); Croatian Bureau of Statistics: Zagreb, Croatia, 2013 
66. City of Rijeka. Strategija razvoja Grada Rijeke za razdoblje 2014.-2020. godine (Development Strategy of the City of Rijeka 2014-2020). 2013. Available online: https://www.rijeka.hr/en/city-government/development-strategy-of-the-city-of-rijeka2014-2020/ (accessed on 1 February 2021).

67. Rijeka ECOC2020. Rijeka's Bid Book for the Title of European Capital of Culture 2020 • Rijeka 2020. 2020. Available online: https:/ / rijeka2020.eu/en/rijekas-bid-book-for-the-title-of-european-capital-of-culture-2020/ (accessed on 1 February 2021).

68. Dutton, C. Le Fantôme de Tito I Reportage I Photononstop. Available online: https:/ /www.photononstop.com/reportages.php? $I d=20 \& P=2007-02$ (accessed on 14 March 2021).

69. Rijeka City Museum. Galeb Ship. 2020. Available online: https://www.muzej-rijeka.hr/en/zbirke/motor-vessel-galeb/ (accessed on 14 March 2021).

70. City of Rijeka. The Conversion and Revitalisation of the Former Complex Rikard Benčić, Rijeka. 2021. Available online: https:/ / www.rijeka.hr/en/city-government/city-projects/ongoing-projects-2/the-redevelopment-and-revitalisation-ofthe-former-rikard-bencic-complex (accessed on 13 March 2021).

71. European Commission. New Cultural Life for Historic Factory Complex in Rijeka, Croatia-Projects. Available online: https: / / ec.europa.eu/regional_policy/en/projects/Croatia/new-cultural-life-for-historic-factory-complex-in-rijeka-croatia (accessed on 17 March 2021).

72. City of Rijeka, Rijeka Exportdrvo, Rijeka. 2021. Available online: https://rijeka2020.eu/en/about-the-project/buildingsrenovation/exportdrvo (accessed on 17 March 2021).

73. Gravagnuolo, A.; Girard, L.F.; Ost, C.; Saleh, R. Evaluation Criteria for a Circular Adaptive Reuse of Cultural Heritage. BDC Boll. Cent. Calza Bini 2017, 17, 185-216.

74. Ost, C.; Saleh, R. Introduction to Perceptions Mapping: The Case of Salerno, Italy. Territorio della Ricerca su Insediamenti e Ambiente. Riv. Internazionale Cult. Urban. 2020, 137-160. [CrossRef]

75. Jokilehto, J. A History of Architectural Conservation, 2nd ed.; Routledge: New York, NY, USA, 2017; ISBN 978-1-138-63998-0.

76. Foster, G. Circular Economy Strategies for Adaptive Reuse of Cultural Heritage Buildings to Reduce Environmental Impacts. Resour. Conserv. Recycl. 2020, 152, 104507. [CrossRef]

77. Ostrom, E. The Future of the Commons: Beyond Market Failure and Government Regulation; Occasional Paper/IEA; Institute of Economic Affairs Monographs: London, UK, 2012; ISBN 978-0-255-36653-3.

78. Ostrom, E. Governing the Commons: The Evolution of Institutions for Collective Action. The Political Economy of Institutions and Decisions; Cambridge University Press: Cambridge, UK; New York, NY, USA, 1990; ISBN 978-0-521-37101-8.

79. Throsby, D. Economics and Culture, 1st ed.; Cambridge University Press: Cambridge, UK, 2000; ISBN 978-0-521-58639-9.

80. Farinelli, F. Geografia: Un'introduzione Ai Modelli Del Mondo; Piccola Biblioteca Einaudi; Giulio Einaudi Editore: Torino, Italy, 2003; ISBN 978-88-06-16020-3.

81. Benjamin, W.; Tiedemann, R.; Benjamin, W. I "Passages" di Parigi; Einaudi: Torino, Itlay, 2000; ISBN 978-88-06-13313-9.

82. Lave, J.; Wenger, E. Situated Learning: Legitimate Peripheral Participation, 1st ed.; Cambridge University Press: Cambridge, UK, 1991; ISBN 978-0-521-41308-4.

83. Norberg-Schulz, C. Genius Loci: Paesaggio, Ambeinte, Architettura; Electa: Milano, Italy, 1992; ISBN 978-88-435-4263-5.

84. Greffe, X. Creativity: The Strategic Role of cultural Landscapes. In Sustainable City and Creativity: Promoting Creative Urban Initiatives; Fusco Girard, L., Nijkamp, P., Baycan, T., Eds.; Taylor and Francis; Routhledge: London, UK, 2012; ISBN 978-1-31561146-4.

85. Council of Europe. CoE Convention on the Value of Cultural Heritage for Society_Faro Convention 2005; CoE: Strasbourg, France, 2005.

86. Miyawaki, A.; Kazue, F.; Box, E. Towards Harmonious Green Urban Environments in Japan and Other Countries. BIEST 1987, 14, 67-82.

87. Peterlin, M.; Očkerl, P.; Gantar, P.; Simoneti, M. Jane's Walk: Urbani Sprehodi za Prijaznejša Mesta: Priročnik za Organizacijo Urbanih Sprehodov; Inštitut za Politike Prostora: Ljubljana, Lituania, 2012; ISBN 978-961-92936-5-2.

88. Santagata, W. Cultural Districts, Property Rights and Sustainable Economic Growth. Int. J. Urban Reg. Res. 2002, 26, 9-23. [CrossRef]

89. Santagata, W. La Fabbrica Della Cultura: Ritrovare la Creatività per Aiutare lo Sviluppo del Paese; Il Mulino: Bologna, Italy, 2007; ISBN 978-88-15-11854-7. 